\title{
Vertical distribution and partitioning of organic carbon in mixed, frontal and stratified waters of the English Channel
}

\author{
P. M. Holligan ${ }^{1}$, R. P. Harris ${ }^{1}$, R. C. Newell ${ }^{2}$, D. S. Harbour ${ }^{1}$, R. N. Head ${ }^{1}$, \\ E. A. S. Linley ${ }^{2}$, M. I. Lucas ${ }^{2}$, P. R. G. Tranter ${ }^{1}$ and C. M. Weekley ${ }^{1}$ \\ ${ }^{1}$ Marine Biological Association. The Laboratory, Citadel Hill, Plymouth PL1 2PB, England \\ ${ }^{2}$ Institute for Marine Environmental Research, Prospect Place, Plymouth PL1 3DH, England
}

\begin{abstract}
The vertical distribution of plankton is described for 3 stations representative of stratified, frontal and vertically mixed regions of the western English Channel in summer. All components of organic carbon, representing dissolved and particulate organic carbon, phytoplankton, bacteria, protozoans, micro- and meso-zooplankton, were estimated independently. Major differences were found in the abundance and species composition of the phytoplankton, and in the relative proportions of different groups of heterotrophs. In the frontal region the phytoplankton $\left(26.5 \mathrm{~g} \mathrm{C} \mathrm{m}^{-2}\right.$ ) was composed of an essentially monospecific, surface population of the dinoflagellate Gyrodinium aureolum; by contrast, under well-stratified conditions small naked flagellates $\left(0.42 \mathrm{~g} \mathrm{C} \mathrm{m}^{-2}\right)$ forming a sub-surface chlorophyll maximum were dominant, and the tidally mixed waters were characterised by diatoms ( $\left.7.91 \mathrm{~g} \mathrm{C} \mathrm{m}^{-2}\right)$. At each station the estimated standing stock of heterotrophs was between 2.3 and $3.2 \mathrm{~g} \mathrm{C}$ $\mathrm{m}^{-2}, 10$ to $30 \%$ of which consisted of bacteria. Hence the phytoplankton was the dominant compartment in the frontal and mixed regions, whereas the zooplankton biomass considerably exceeded that of the phytoplankton in the well-stratified water. The ecological implications of these carbon distribution patterns are discussed.
\end{abstract}

\section{INTRODUCTION}

In the temperate shelf waters around the British Isles plankton distributions are determined directly by water movement (Southward, 1962; Fraser, 1965) and indirectly by the effects of tidal mixing and seasonal stratification (Pingree et al., 1978) on species succession and survival (see references in Holligan, 1981). Since the pioneering work of Lohmann (1908), Harvey (1950) and Krey (1956), no comprehensive study has been made of the structure of plankton communities in offshore waters. In this paper a quantitative comparison of the partitioning of organic carbon at stations in stratified, frontal and mixed waters is presented. Contemporary measurements of photosynthesis and respiration are described by Holligan et al. (1984). The observations were made in midsummer when the influence of the thermocline is most pronounced and when the distribution of carbon in the planktonic ecosystem is most likely to approach a steady-state condition.
Biomass data in units compatible with measured rates of production (e.g. autotrophic and heterotrophic carbon assimilation) are essential for calculating the specific growth rates of organisms or the potential for energy transfer from one trophic level to another. Despite the considerable effort given to numerical models of marine ecosystems (Platt et al., 1981) there is still little information available on the relative abundance of organisms at each trophic level especially for different hydrographic environments. Field studies have generally been confined to a part of the food-web (e.g. Smetacek, 1981; Beers et al., 1982), and the most complete set of published data is for the carbon biomass of bacteria, phytoplankton, ciliates and herbivorous and carnivorous zooplankton in the CEPEX enclosures (Grice et al., 1980).

In the present study, as in the CEPEX project, we have combined the work of a group of individuals using a variety of methods for estimating the numerical abundance and determining the carbon biomass of all the major taxonomic or size categories within the 
plankton. This approach, first applied over 70 y ago (Lohmann, 1908), provides the type of biological information required to elucidate trophic interactions within heterogeneous plankton communities. Indirect methods such as electronic particle counters (e.g. Sheldon et al., 1972; Herman and Mitchell, 1981) and biochemical measurements to distinguish living and non-living material (Hobbie et al, 1972), although less time-consuming, do not offer this important advantage.

\section{SAMPLING AND ANALYTICAL METHODS}

The positions of the sampling stations in stratified (E5), frontal (F) and mixed (M) waters are shown in Fig. 1 in relation to the surface temperature distribution for $0913 \mathrm{~h}$ GMT, 29 July 1981. The water depths were 120,96 and $76 \mathrm{~m}$ respectively. Stations E5 and M were located in mid-channel, $>35 \mathrm{~km}$ from the nearest land, to either side of the mean predicted position (Pingree et al., 1978) of the Ushant tidal front. The site of Station $\mathrm{F}$ was selected during the cruise in a region with a relatively shallow $(<20 \mathrm{~m})$ thermocline and with high surface chlorophyll a levels, features that are characteristic of frontal conditions. The periods of observations were: $1200 \mathrm{~h}, 23$ July to $1730 \mathrm{~h}, 25$ July at M; $0500 \mathrm{~h}, 26$ July to $1300 \mathrm{~h}, 28$ July at E5; and $0500 \mathrm{~h}$, 30 July to $08302 \mathrm{~h}$. August at $\mathrm{F}$. At each station vertical pump profiles were made every $3 \mathrm{~h}$ for at least one $24 \mathrm{~h}$ period and at less frequent intervals for the remainder of the time. The position of each profile was corrected for tidal displacement, using information from Admiralty tidal charts, so that the horizontal distributions of hydrographic properties could be plotted.

Vertical profiles of hydrographic and biological properties were obtained by raising the intake hose $(5 \mathrm{~cm}$ internal diameter) of the submersible pump (Flygt Pumps Ltd., Model B2051, giving an average flow rate of $160 \mathrm{l} \mathrm{min}^{-1}$ ) from $60 \mathrm{~m}$ to $2 \mathrm{~m}$ in steps of $2 \mathrm{~m}$ $\mathrm{min}^{-1}$. Temperature measurements were made with a platinum resistance thermometer (Rosemount Engineering Co. Ltd., Model E12767) positioned in the main outflow. The water was subsampled for a Turner Model III fluorometer, fitted with filters appropriate for detecting chlorophyll a fluorescence (Holm-Hansen et al., 1965), and a nutrient autoanalyser (Chemlab Instruments Mk III multi-channel colorimeter) giving continuous records of nitrate (Strickland and Parsons, 1972), as well as nitrite, ammonium and silicate. The remaining water was filtered through $200 \mu \mathrm{m}$ and $80 \mu \mathrm{m}$ nets in series to collect the zooplankton. The nets were suspended in a reservoir of sea water, and a valve system enabled samples to be taken as a continuous series through the water column. Each size fraction was subsampled by a stempel pipette for determina- tions of particulate carbon and nitrogen, the rest being preserved in $5 \%$ neutral formalin for counting. Additional zooplankton samples were taken with paired $200 \mu \mathrm{m}$ WP-2 nets (UNESCO, 1968), both for the whole water column and for the upper $60 \mathrm{~m}$, to compare with the pump system.

In the laboratory, water from the outflow of the fluorometer was collected in 201 carboys to give a series of integrated samples corresponding to successive depth intervals in the water column. After thorough stirring these were each sampled for analyses of particulate and dissolved organic material, and for plankton and particle counts.

Total particle volume and particle size distribution over a diameter range 2 to $100 \mu \mathrm{m}$ were measured for fresh, untreated water samples with a model TA II Coulter Counter, using 100 and $400 \mu \mathrm{m}$ orifices. Each analysis was performed in triplicate.

Chlorophyil $a$ and phaeopigments were estimated by filtering 5 to $200 \mathrm{ml}$ of sea water on to $0.45 \mu \mathrm{m}$ membrane filters and measuring the fluorescence of $90 \%$ acetone extracts before and after the addition of two drops of $10 \% \mathrm{HCl}$ (Lorenzen, 1966). The fluorometer was calibrated each day with a solution of pure chlorophyll a (Sigma Chemical Co.), the concentration of which was determined spectrophotometrically at the start and end of the cruise (Lorenzen, 1967).

Samples for particulate organic carbon (POC) and nitrogen (PON), and dissolved organic carbon measurements were obtained by screening sea water through a $200 \mu \mathrm{m}$ mesh net to remove the larger zooplankton and then filtering 100 to $1000 \mathrm{ml}$, depending on the load of particulate material, through pre-ashed $\left(400^{\circ} \mathrm{C}\right.$ for $\left.6 \mathrm{~h}\right), 25 \mathrm{~mm}$ Whatman $\mathrm{GF} / \mathrm{C}$ glass fibre filters under a vacuum of $<12 \mathrm{~cm} \mathrm{Hg}$. The filters were stored at $-20^{\circ} \mathrm{C}$, and then oven dried at $55^{\circ} \mathrm{C}$ prior to analysis with a Carlo Erba elemental analyser (Model 1106) calibrated with cyclohexanone or 1:5 diphenylcarbazide standards. Analyses of a series of duplicate samples gave standard deviations of $\pm 10 \%, \pm 22 \%$, and $\pm 18 \%$ for the estimates of POC, PON and POC/ PON from single determinations. Triplicate $8 \mathrm{ml} \mathrm{sam-}$ ples of the filtrate were transferred to precombusted $15 \mathrm{ml}$ glass vials, and $75 \mu \mathrm{l} 1 \mathrm{~N} \mathrm{HCl}$, made up in carbon-free distilled water prepared by ultra-violet irradiation, was added to dispel inorganic carbon as carbon dioxide. The vials were then sealed with Teflon-lined caps and stored at $-20^{\circ} \mathrm{C}$. Dissolved organic carbon in the filtrates was measured by the ultra-violet photooxidation method of Collins and Williams (1977), as modified by Gershey et al. (1979). Potassium oxalate (Analar grade), dissolved in carbon-free distilled water, was used as a standard.

Water samples were preserved with Lugols iodine solution (Holligan and Harbour, 1977) and $0.5 \%$ neu- 
tralised formalin for counts of phytoplankton and protozoans, and in $2.5 \%$ glutaraldehyde for counts of bacteria. The latter were stored at $5^{\circ} \mathrm{C}$ in pre-sterilised scintillation vials.

Light measurements were made with 2 Underwater Quantum sensors 400 to 700 nm (Crump Scientific Products Ltd., Model 552), one fixed to the superstructure of the ship to give surface irradiance and the other lowered into the water column to $40 \mathrm{~m}$ to record downwelling irradiance.

\section{SPECIES IDENTIFICATION AND CARBON BIOMASS ESTIMATES}

\section{Phytoplankton and protozoans}

Cell counts were made on settled 10 to $100 \mathrm{ml} \mathrm{sam-}$ ples (depending on the chlorophyll a concentration) with an inverted microscope using $\times 187$ and $\times 750$ magnifications. Carbon estimates for each species were derived from volume determinations (Kovala and Larrance, 1966) and the cell volume/carbon relationships given by Eppley et al. (1970) (see also UNESCO, 1974 - footnote on p. 11). The only exceptions to this procedure were that, for Noctiluca scintillans and for all ciliates, the carbon conversion factors given respectively by Dewey (1976) and by Beers et al. (1975) were applied.

To assess counting errors, and also the range in variation in cell volume for the major species, 5 replicates from the chlorophyll maximum layer at each of the 3 stations were counted and volumes for at least 40 cells of each of the dominant species determined (Table $1 \mathrm{~b}$ ). The replicate counts gave maximum standard deviations of $\pm 12 \%, \pm 3.4 \%$ and $\pm 4.2 \%$ for cell numbers of flagellates, Rhizosolenia stolterfothii and Gyrodinium aureolum respectively.

\section{Bacteria}

Bacterial numbers were estimated using an acridine orange epifluorescence direct counting technique after collection on $0.2 \mu \mathrm{m}$ Nuclepore filters (Hobbie et al., 1977). The relative frequency and mean cell volumes of up to six size/shape categories of bacteria were obtained from enlarged photographs (Fuhrman, 1981). Bacterial carbon biomass was then calculated using the weighted mean cell volume estimates, a specific gravity of $1.1 \mathrm{~g} \mathrm{~cm}^{-3}$ (Doetsch and Cook, 1973) and a carbon to wet biomass ratio of 0.1 (Straškrabová and Sorokin, 1972).

Replicate bacterial counts and the relative frequencies of the main cell types gave maximum standard deviations between $\pm 4.5 \%$ and $\pm 6.7 \%$ whilst standard errors of biovolume estimates for each cell type ranged from $\pm 3.7 \%$ to $\pm 9.3 \%$ of the mean values.

\section{Micro and mesozooplankton}

Zooplankton species counts were made on subsamples examined under a stereomicroscope, and identifications were confirmed under higher magnification using an inverted microscope. The fraction retained by the $80 \mu \mathrm{m}$ mesh and passing through $200 \mu \mathrm{m}$ (80 to $200 \mu \mathrm{m}$ ) was used to obtain estimates of microzooplankton (copepod nauplii and early copepodites, invertebrate larvae).

Subsamples from this size fraction were typically about $1 / 100$, giving counts of at least 100 individuals for dominant groups such as copepod nauplii. Mesozooplankton retained on a $200 \mu \mathrm{m}$ mesh were estimated from a $1 / 4$ to $1 / 8$ subsample, with the total sample being examined for some rarer groups. Counts of dominant copepods on replicate net samples gave a standard deviation of about $\pm 25 \%$ of the mean.

Zooplankton carbon and nitrogen were estimated directly by filtering between $1 / 4$ and $1 / 8$ of the fresh zooplankton samples onto pre-ashed GF/C pads. These aliquots were stored at $-20^{\circ} \mathrm{C}$ within $10 \mathrm{~min}$ of collection, and subsequently dried at $60^{\circ} \mathrm{C}$ for $24 \mathrm{~h}$ before weighing on a Cahn Electrobalance. The zooplankton and filter were then ground in an agate ball mill and subsampled for analysis on the Carlo Erba elemental analyser (see previous section).

\section{RESULTS}

\section{Summary of observations}

Hydrographic observations

At the end of July 1981, the surface temperature structure in the western English Channel (Fig. 1) was characterised by anomalously warm water in the central region, and relatively weak horizontal gradients across the frontal boundary between cool mixed waters off the coast of France and the warmer stratified water to the north and west. The area of high surface temperatures (up to $18.2^{\circ} \mathrm{C}$ on $28-29$ July) corresponded to the distribution of a surface bloom of the dinoflagellate Gyrodinium aureolum which had developed to the stratified side of the frontal boundary during the preceding 4 wk (Holligan et al., 1983). Surface temperatures in the stratified water at E5, at the western edge of the bloom, were 16 to $17^{\circ} \mathrm{C}$ and in the mixed water ranged from $13.0^{\circ} \mathrm{C}$ north of Ushant to $\sim 14.6{ }^{\circ} \mathrm{C}$ 


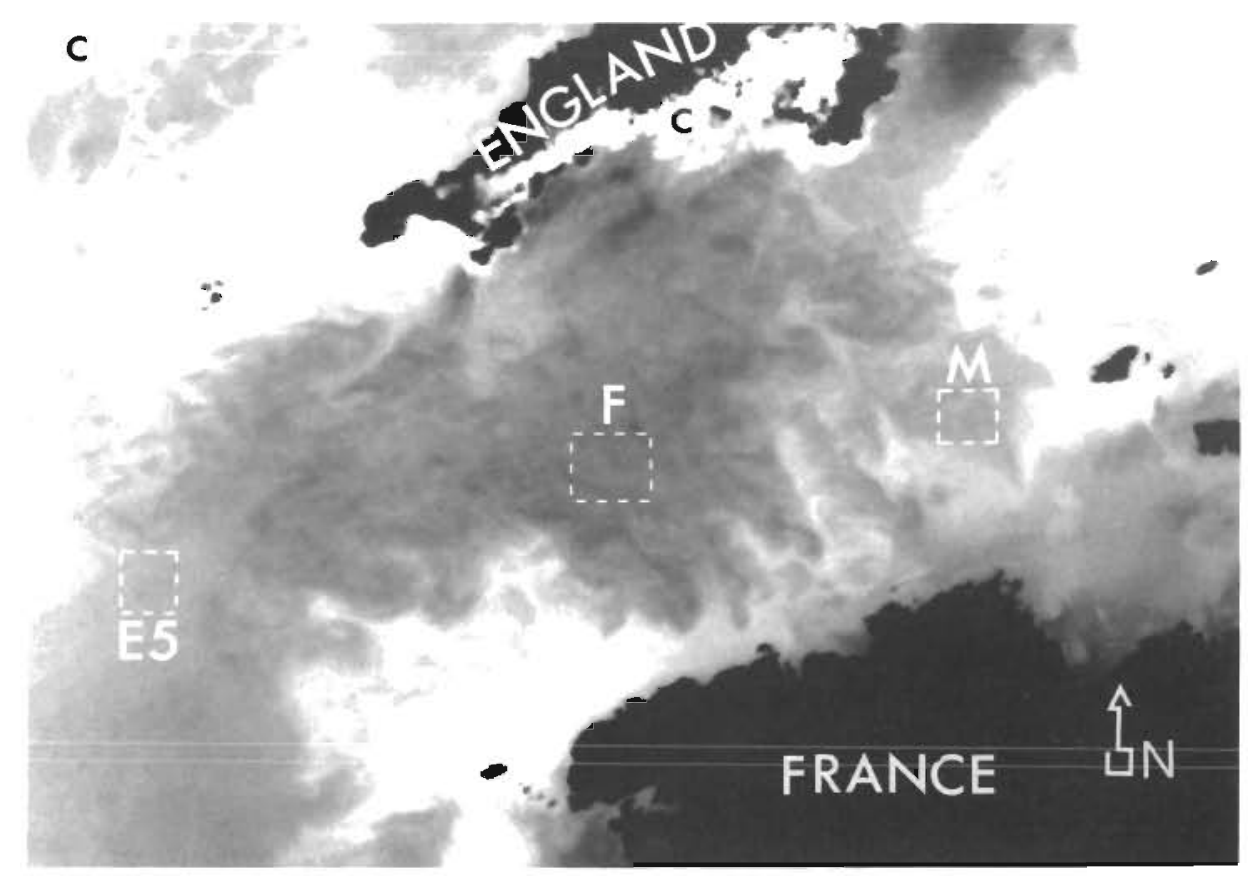

Fig. 1. Infra-red satellite (NOAA-7) image of western English Channel for 29 July 1981 (1353 h GMT), showing sampling regions in stratified (E5), frontal $(F)$ and mixed $(M)$ waters. Light areas off N. W. France, around the Scilly Isles and to the northwest of Station $M$ indicate relatively cool surface water. $\mathrm{C}=$ clouds

around Station $M$. The variations in temperature of the mixed water are clearly shown in Fig. 1, and the position of the tidal front about half-way between Stations $F$ and $M$ could only be identified with certainty on the satellite image from the ship measurements of vertical temperature gradients.

At E5 the thermocline was typically 20 to $25 \mathrm{~m}$ deep, with a temperature change of 5 to $6 \mathrm{C}^{\circ}$, and characterised by a subsurface chlorophyll maximum and a marked nitrate gradient from $<0.1 \mu \mathrm{M}$ in the surface layer to $-4 \mu \mathrm{M}$ in the bottom layer (Fig. 6). By contrast, in the mixed water at Station $M$ the increase in temperature above $60 \mathrm{~m}$ was always $<0.3 \mathrm{C}^{\circ}$ and generally about $0.1 \mathrm{C}^{\circ}$; profiles of chlorophyll fluorescence were uniform with depth, although measured concentrations of chlorophyll a usually decreased towards the surface, and nitrate levels were about $1 \mu \mathrm{M}$ throughout the water column. The frontal region $(F)$ showed an intermediate temperature distribution, with the main thermocline at about $16 \mathrm{~m}$ and a surface to bottom temperature difference of 3 to $5 \mathrm{C}^{\circ}$, and high surface chlorophyll levels which extended into the thermocline layer on some profiles. The nitrate concentrations below the thermocline were remarkably low $(<0.3 \mu \mathrm{M}$ compared to expected values of 2 to $3 \mu \mathrm{M}$ for this degree of stratification in August), apparently due to assimilation by the dinoflagellate population (Holligan et al., 1984).

Offshore surface salinities increased from about $34.6 \%$ in the east (Station $M$ ) to $35.1 \%$ in the west (E5). Salinity differences between $60 \mathrm{~m}$ and the surface were $<0.02 \%$ at $M$ and $<0.05 \%$ at $F$ and E5, so that temperature changes were dominant in determining vertical density gradients.

Extinction coefficients for visible light (400 to $700 \mathrm{~nm}$ ) in the surface layers were related to chlorophyll concentrations and ranged between 0.11 and $0.20 \mathrm{~m}^{-1}$ at E5, 0.44 to $0.85 \mathrm{~m}^{-1}$ at $F$, and 0.17 and $0.20 \mathrm{~m}^{-1}$ at $\mathrm{M}$.

Spatial variability in the abundance of particulate material and plankton

Data on the standing stocks of chlorophyll $a$ and particulate organic carbon (POC) in the upper $30 \mathrm{~m}$ of the water column for the 3 stations are shown in Fig. 2. Values for E5 and F include both the thermocline and surface layers (i.e. the effective euphotic zone) and show wide variations in phytoplankton abundance. Regression analyses, using the geometric mean method of Ricker (1973), yield POC to chlorophyll ratios of 81 and 74 respectively, although for both stations the correlation coefficients were relatively low. The data points for the mixed water are closely grouped and indicate no consistent relationship between the two parameters.

The variations in chlorophyll abundance show coherent patterns of horizontal distribution at each station (Fig. 3A) which are in good agreement with both the phytoplankton cell counts (e.g. Fig. 8B) and the satellite image of surface chlorophyll distribution on 29 July (Holligan et al., 1983). At the mixed water and frontal stations, where chlorophyll levels 


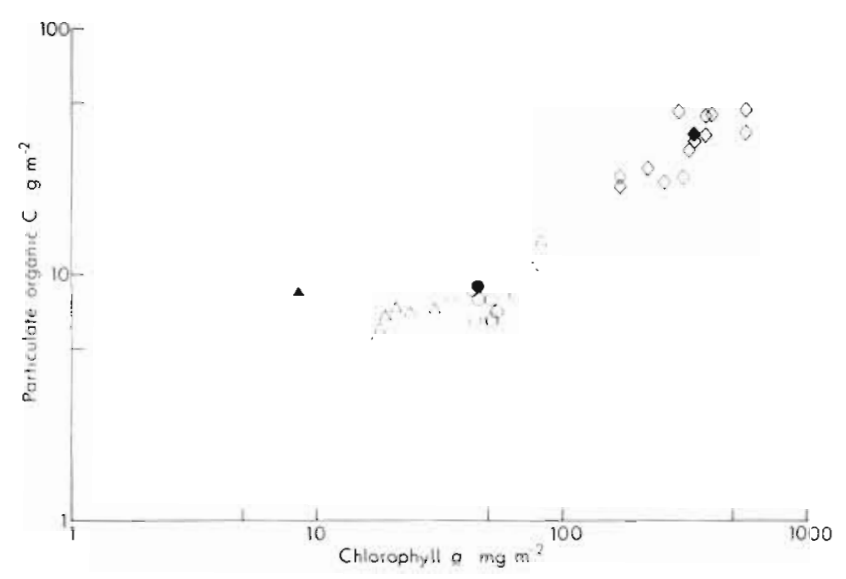

Fig. 2. Standing stocks of particulate organic carbon $<200$ $\mu \mathrm{m})$ and chlorophyll $a$ in the upper $30 \mathrm{~m}$ of the water column, both plotted on log scales, at Stations E5 $(\Delta), F(\diamond)$ and $M(O)$. Solid symbols: values obtained on reference profiles for which the detailed analyses of plankton samples were made. Geometric mean regression equations give for $E 5, P O C=$ 0.0805 chl. $a+4.47(\mathrm{r}=0.62, \mathrm{~N}=18)$, and for $\mathrm{F}, \mathrm{POC}=$ 0.0739 chl. $a+10.0(\mathrm{r}=0.73, \mathrm{~N}=14)$

increased towards the north west, the dominant phytoplankton were, respectively, diatoms (mainly Rhizosolenia stolterfothin) and the dinoflagellate Gyrodinium aureolum. Station E5 exhibited a subsurface tongue of chlorophyll- and Gyrodinium-rich water extending between low chlorophyll regions to the southwest and northeast where the phytoplankton was composed mainly of small $(<10 \mu \mathrm{m}$ diameter), naked flagellates.

Comparable data on zooplankton are presented in
Fig. 3B for copepod nauplii in the surface $30 \mathrm{~m}$, this group being chosen as an example of non-migratory organisms which feed mainly on phytoplankton. In the mixed water the distribution of nauplii was relatively uniform (variance to mean ratio 12.7), higher densities being found on the southern profiles. In the frontal region the mean densities differed by a factor of 6 , giving a variance to mean ratio of 80.6 , with the highest values towards the northeast. At Station E5, where the copepod nauplii were generally most abundant, the variance to mean ratio of 44.0 was intermediate. In no case was there any obvious relationship between the distribution of chlorophyll and nauplii.

\section{Carbon to nitrogen ratios of particulate material}

Measurements of POC and PON are summarised in Fig. 4. Geometric mean regression (Ricker, 1973) gives carbon to nitrogen ratios of 8.5 for the mixed water column, 8.1 for the frontal station and 7.7 (surface and thermocline layers) and 10.3 (bottom layer) for the stratified waters at E5. Each regression line yielded a positive POC intercept value, suggesting that some of the particulate carbon was not associated with nitrogen. The correlation coefficients were high for the samples from Station F, where phytoplankton formed the bulk of the particulate material, but relatively low at the other 2 stations. The increase in the carbon to nitrogen ratio for particulate material below the thermocline at E5 indicates some preferential removal of
Fig. 3. Distributions of chlorophyll a, $\mathrm{mg} \mathrm{m}^{-2}$ (A) and copepod nauplii, $\times 10^{-3} \mathrm{~m}^{-2}$ (B) in the upper $30 \mathrm{~m}$ of the water column at Stations E5, $F$ and $M$. Dots show sampling positions, those enclosed by circles indicating reference profiles

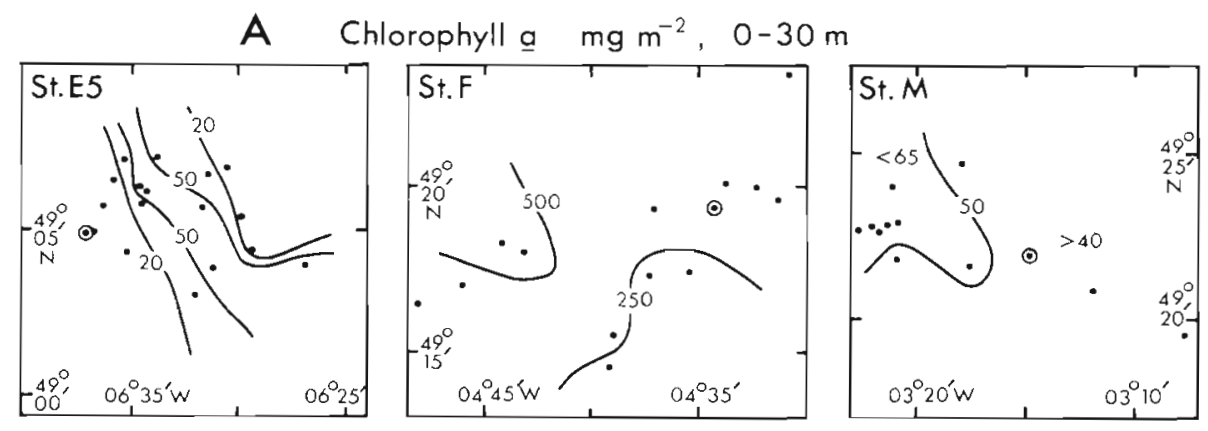

B Copepod nauplii no. $\mathrm{m}^{-2} \times 10^{-3}, 0-30 \mathrm{~m}$

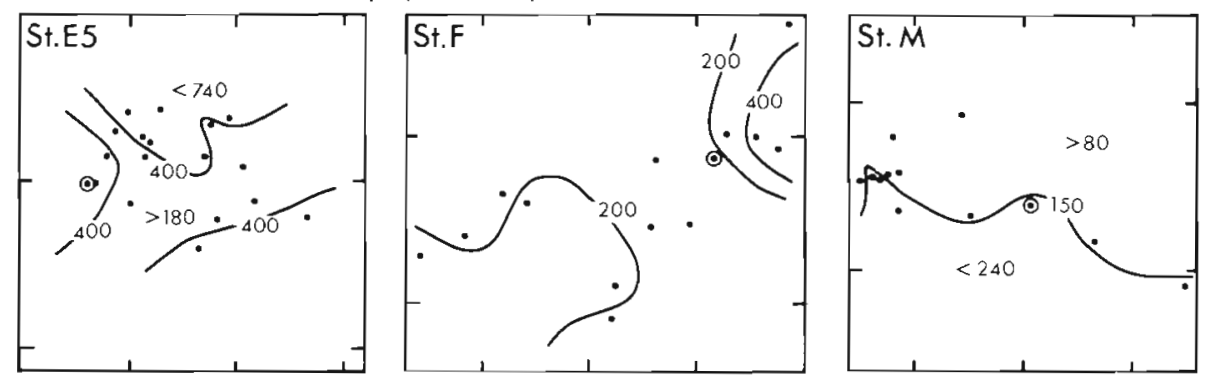




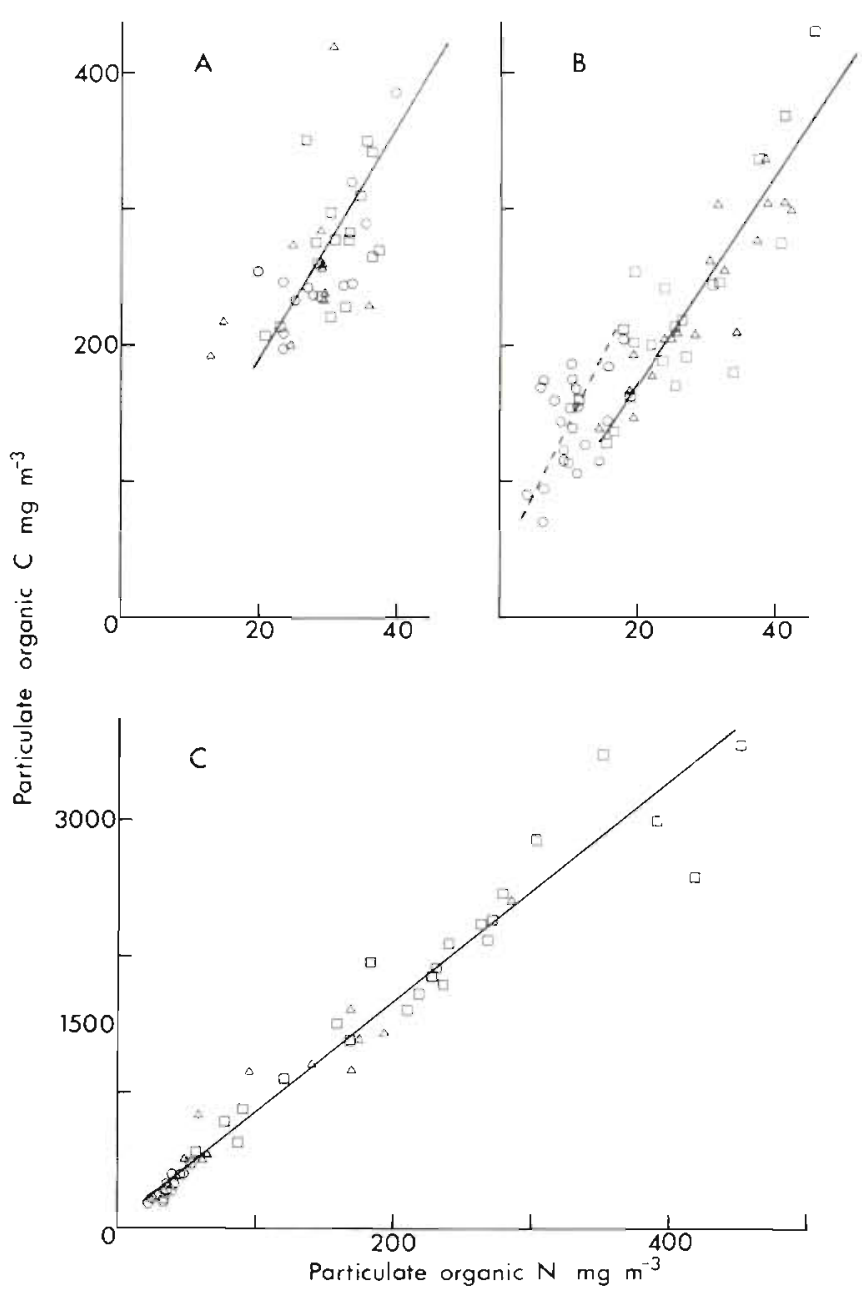

Fig. 4. Particulate organic $C$ and $N(<200 \mu \mathrm{m})$ analyses for (A). Station $M(\square, 2-20 \mathrm{~m} ; \Delta, 20-40 \mathrm{~m} ; \mathrm{O}, 40-60 \mathrm{~m})$; (B) Station E5 $(\square, 2-20 \mathrm{~m} ; \triangle, 20-30 \mathrm{~m} ; \mathrm{O}, 30-60 \mathrm{~m}) ;$ (C) Station $\mathrm{F}(\square, 2-10$ $\left.\mathrm{m}_{i} \Delta, 10-30 \mathrm{~m} ; 0,30-60 \mathrm{~m}\right)$. Regression equations are for $M$, all samples $\mathrm{C}=8.51 \mathrm{~N}+19.61(\mathrm{r}=0.57, \mathrm{~N}=40)$; for $E 5$, $2-20 \mathrm{~m}$ and $20-30 \mathrm{~m}$ samples $\mathrm{C}=7.70 \mathrm{~N}+17.57(\mathrm{r}=0.86, \mathrm{~N}$ $=39)$ and $30-60 \mathrm{~m}$ samples $\mathrm{C}=10.31 \mathrm{~N}+40.87(\mathrm{r}=0.51, \mathrm{~N}$ $=21)$; for $F$, all samples $C=8.12 N+47.38(r=0.98, N=59)$

nitrogen relative to carbon by recycling processes within the bottom water.

The micro- and mesozooplankton samples for all 3 stations showed a consistent carbon to nitrogen ratio of 4.4 (Fig. 5), almost half the value for the particulate materials available to the animals as food. This implies that for a wide range of grazing conditions, both in terms of the type and concentration of food and of herbivore species, the assimilation efficiency for nitrogen is about twice that for carbon. Furthermore, the good correlations between carbon and nitrogen for the plankton (Fig. 4C and 5) allow inferences to be made about the distribution of nitrogen from data on carbon alone.

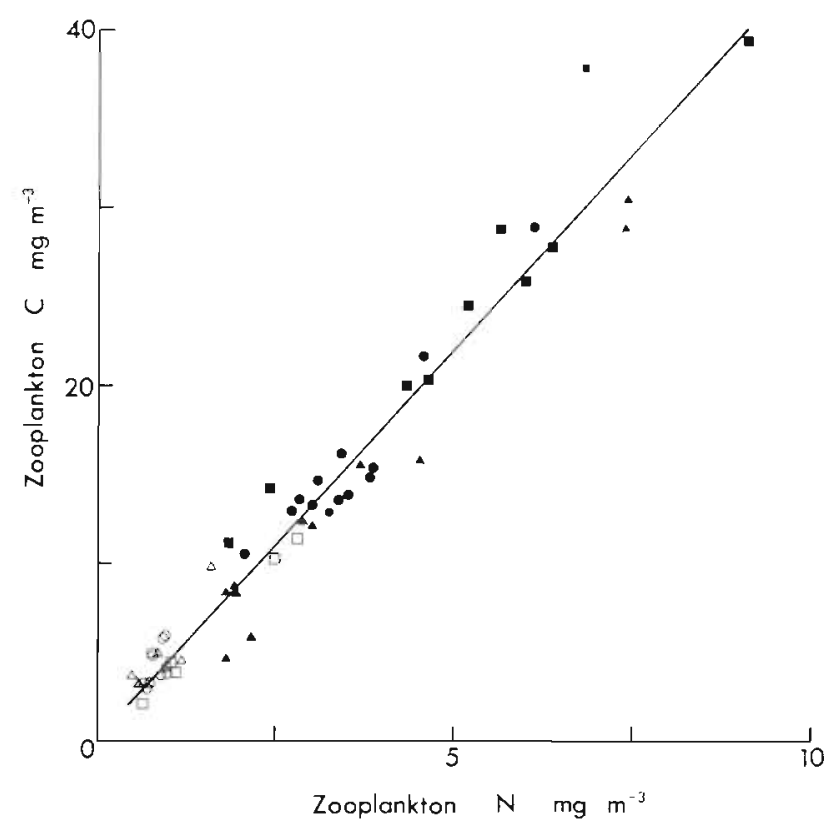

Fig. 5. Microzooplankton (80 to $200 \mu \mathrm{m}$, open symbols) and mesozooplankton (>200 $\mu \mathrm{m}$, closed symbols) $\mathrm{C}$ and $\mathrm{N}$ analyses for Stations E5 ( $\square$ ). F $(\Delta)$ and $M(0)$. The common regression equation is $\mathrm{C}=4.40 \mathrm{~N}+0.103(\mathrm{r}=0.98, \mathrm{~N}=56)$

\section{Vertical distributions}

A detailed comparison of the vertical distributions and relative abundance of the various components of the plankton was made for one reference profile (Fig. 3) at each of the 3 stations. The water was sampled over 5 intervals, each corresponding to a depth range of $12 \mathrm{~m}$. At E5 the sampling was carried out in the chlorophyll-poor water to the west, where small flagellates dominated the phytoplankton, in order to make the comparison with the dinoflagellate and diatom populations at Stations $\mathrm{F}$ and $\mathrm{M}$.

\section{Hydrographic properties}

The chlorophyll maximum at E5 was situated within the thermocline and associated with the nitrate gradient (Fig. 6). High concentrations of chlorophyll also extended to the base of the thermocline at Station F; the temperature inversions and related chlorophyll minima apparent on the profiles were probably caused by internal waves. In the mixed water slight variations in the vertical distributions of chlorophyll and nitrate were observed despite the absence of significant temperature (density) structure. The depth of the $1 \%$ light level ranged from $36 \mathrm{~m}$ at $\mathrm{E} 5$, well below the thermocline and chlorophyll maximum, to $<10 \mathrm{~m}$ in the frontal region where Gyrodinium aureolum was abundant. 
Fig. 6. Vertical distributions of temperature $\left({ }^{\circ} \mathrm{C}\right)$, chlorophyll a ( $\left.\mathrm{mg} \mathrm{m}^{-3}\right)$, nitrate $(\mu \mathrm{M})$ and downwelling irradiance (relative to a maximum subsurface value of 100 ) in upper $60 \mathrm{~m}$ of the water column for the reference profiles at Stations E5 (dashed lines), F (dotted lines) and $M$ (solid lines). The low scales for chlorophyll apply to $\mathrm{E} 5$ and $\mathrm{M}$, and for nitrate to $F$ and $M$. Arrows: depths of $1 \%$ light levels

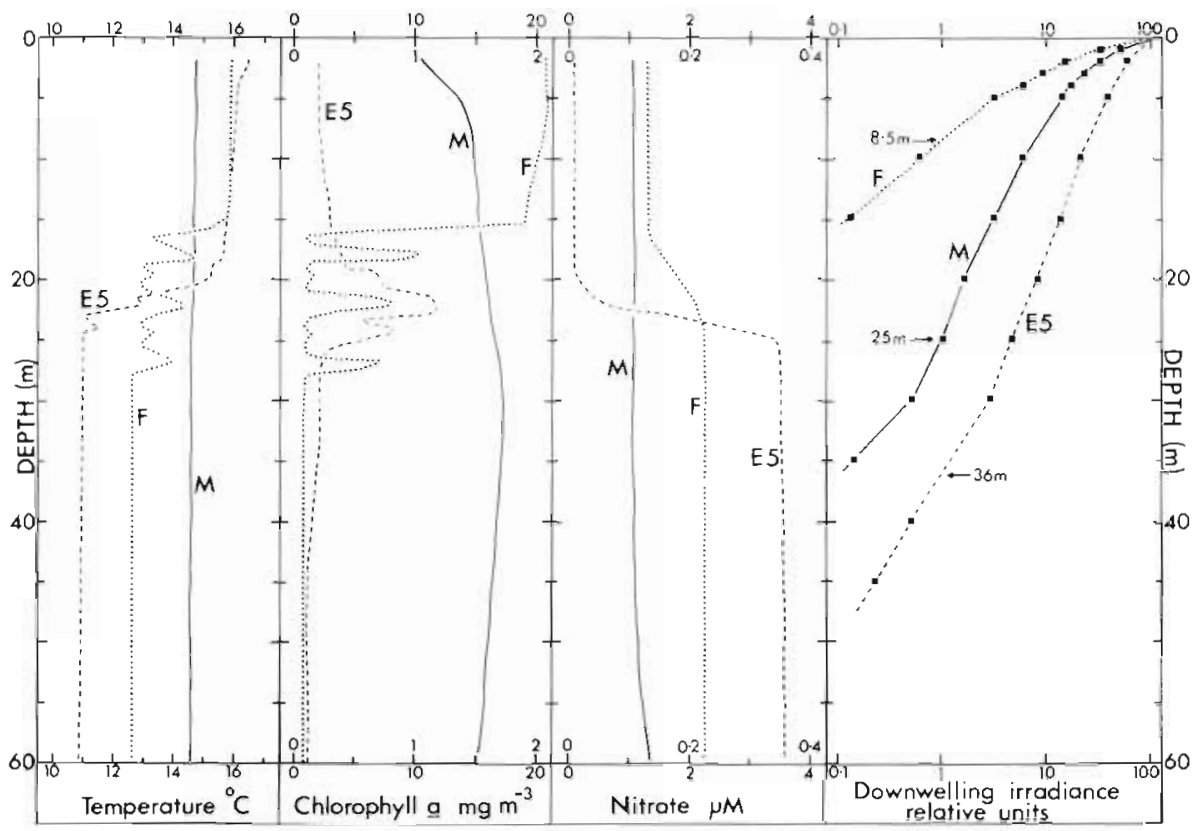

Particle concentrations were lowest throughout the water column at the stratified station, E5, being generally below $0.05 \mathrm{ppm}$ across the entire size spectrum (Fig. 7). In the combined surface and thermocline layers there was a small peak in the range 3 to $6 \mu \mathrm{m}$, presumably representing the heterogeneous population of small flagellates, and a larger maximum between 20 and $25 \mu \mathrm{m}$ apparently reflecting the presence of larger phytoplankton and protozooplankton in the thermocline (Table 1a). The particulate matter in the surface waters was relatively rich in carbon, $1 \mathrm{ppm}$ being equivalent to $228.7 \mathrm{mg}$ POC $\mathrm{m}^{-3}$ $\left(1 \mu \mathrm{m}^{3}=0.23 \mathrm{pg} \mathrm{C}\right)$. This may reflect the relatively high carbon per unit cell volume for the small flagellates, but is probably related to the large proportion of uncharacterised carbon or 'detritus' (Table 4).

In the surface $24 \mathrm{~m}$ at the frontal station $\mathrm{F}$ the total particle volume was over an order of magnitude higher than in surface stratified waters. The particle-size spectrum was dominated by the Gyrodinium population, with a biomass maximum of over $6 \mathrm{ppm}$ in the 16 to $20 \mu \mathrm{m}$ channel representing 2041 particles (cells) $\mathrm{ml}^{-1}$. In addition, the background of small particles between 2 and $10 \mu \mathrm{m}$ was considerably higher than at the other 2 stations, and the carbon content per unit volume of total particulate material was considerably lower than at E5, $1 \mathrm{ppm}$ being equivalent to $79.2 \mathrm{mg}$ POC $\mathrm{m}^{-3}$. Below the thermocline total particle volume was over an order of magnitude lower, and was uniformly distributed with respect to particle size.

At the mixed water station, $M$ the particle size distribution was similar throughout the water column and was dominated by a biomass maximum in the region of $50 \mu \mathrm{m}$, corresponding to the diatom population (Table
At the mixed water station intermediate conditions prevailed in terms of both light penetration and surface chlorophyll levels.
Fig. 7. Particle-size analyses, based on assumed spherical dimensions, for integral surface (0 to $24 \mathrm{~m}$, solid lines) and sub-surface (24 to $60 \mathrm{~m}$, dotted lines) water samples obtained for the reference profiles at Stations E5, F and M. Each data point represents the mean of 3 determinations 
Table 1a. Vertical distribution of phytoplankton and protozoans (cells $\mathrm{ml}^{-1}$ )

\begin{tabular}{|c|c|c|c|c|c|c|}
\hline \multirow[t]{2}{*}{ Taxa } & \multirow[t]{2}{*}{ Station } & \multicolumn{5}{|c|}{ Depth $(\mathrm{m})$} \\
\hline & & $2-12$ & $12-24$ & $24-36$ & $36-48$ & $48-60$ \\
\hline \multirow{3}{*}{ Rhizosolenia stolterfothii } & ES & - & - & - & - & - \\
\hline & $F$ & - & - & - & - & - \\
\hline & M & 40 & 42 & 47 & 46 & 51 \\
\hline \multirow[t]{3}{*}{ Other diatom spp. } & E5 & $.09(3)$ & $.55(10)$ & $3.94(10)$ & $5.18(12)$ & $3.54(13)$ \\
\hline & $\mathrm{F}$ & $3.3 \quad(6)$ & .9 (3) & $1.0 \quad(2)$ & 1.1 (6) & $.7 \quad(2)$ \\
\hline & M & $29.44(24)$ & $39.48(22)$ & $44.28(25)$ & $41.72(24)$ & $47.20(24)$ \\
\hline \multirow[t]{3}{*}{ Gyrodinium aureolum } & E5 & .07 & .08 & .05 & .03 & .02 \\
\hline & $F$ & 2649 & 998 & 117 & 61 & 69 \\
\hline & M & - & .02 & - & .01 & .01 \\
\hline \multirow{3}{*}{$\begin{array}{l}\text { Other photosynthetic } \\
\text { dinoflagellates }\end{array}$} & E5 & $.72(7)$ & $4.49(9)$ & .45 (5) & $.15(2)$ & $.16(3)$ \\
\hline & $\mathrm{F}$ & $12.4 \quad(7)$ & $6.2 \quad(7)$ & $1.0 \quad$ (4) & $1.0 \quad$ (4) & $.7 \quad(3)$ \\
\hline & M & $17.46(7)$ & $.84 \quad(5)$ & $.52(4)$ & $.55(6)$ & $.34(6)$ \\
\hline \multirow[t]{3}{*}{ Flagellates } & E5 & 1848 & 1746 & 511 & 497 & 486 \\
\hline & $F$ & 3576 & 2160 & 535 & 475 & 421 \\
\hline & M & 813 & 878 & 1175 & 969 & 1177 \\
\hline \multirow{3}{*}{$\begin{array}{l}\text { Non-photosynthetic } \\
\text { dinoflagellates }\end{array}$} & E5 & 1.02 & $.72(6)$ & $.27 \quad(5)$ & $.22(4)$ & $.59(6)$ \\
\hline & $\mathrm{F}$ & $30.2 \quad(10)$ & $14.1 \quad$ (9) & $1.7 \quad(7)$ & 1.1 (5) & $.9 \quad(6)$ \\
\hline & $M$ & $2.49(12)$ & $1.92(9)$ & 2.39 (12) & $2.33(10)$ & $1.91(10)$ \\
\hline \multirow[t]{3}{*}{ Ciliates } & E5 & 1.31 & 6.61 & .67 & .41 & .55 \\
\hline & $\mathrm{F}$ & 3.3 & 2.1 & .9 & 1.1 & 6 \\
\hline & M & .79 & 1.27 & 1.22 & 1.36 & .95 \\
\hline
\end{tabular}

1a). The carbon content per unit volume of the particulate matter was comparable to that in the surface $24 \mathrm{~m}$ in the frontal region, $1 \mathrm{ppm}$ representing $88.9 \mathrm{mg}$ POC $m^{-3}$.

\section{Phytoplankton and protozoans (Table 1)}

At all 3 stations flagellates were numerically the most abundant phytoplankton although, in terms of carbon biomass, they were dominant only at E5. With the light microscope it was not possible to obtain useful taxonomic information about this group, or to determine whether individual cells contained chlorophyll. The count and biomass data for the flagellates include therefore unknown proportions of heterotrophic forms which, in a functional sense, should be assigned to the protozoans. In the surface layer at E5, the high phytoplankton carbon to chlorophyll ratio (Table 5) suggests that $>50 \%$ of the flagellate carbon could have been attributable to nonphotosynthetic species. The distribution of Gyrodinium aureolum corresponded to the extent of the surface bloom $\left(\sim 30,000 \mathrm{~km}^{2}\right)$ around Station $F$ (see Holligan et al., 1983), with very low densities even in the thermocline at E5. The phytoplankton in the mixed water included many species of diatoms, in particular Rhizosolenia stolterfothii and $R$. hebetata. Among the protozoans, including the non-photosynthetic dinoflagellates, the most important species were the dinoflagellates Noctiluca scintillans (up to $8 \times 10^{6}$ cells $\mathrm{m}^{-2}$ in the $G$. aureolum bloom) and Gyrodinium aff. spirale, and the loricate tintinnid Helicostomella sp. which was most abundant in the thermocline at E5.

Vertical distribution patterns were consistent with the hydrographic data, with good correspondence between chlorophyll and phytoplankton counts (compare Fig. 6 and Table 1a) and with the main changes in species composition occurring at the level of the thermocline. Other notable features were the increase in diatoms below the thermocline at E5 (the benthic species Paralia sulcata was most abundant), the relatively high densities of flagellates below the thermocline at all 3 stations, and the increase in dinoflagellates in the upper $12 \mathrm{~m}$ at Station $\mathrm{M}$ contrasting with decreases in chlorophyll and diatom abundance in the same layer.

Measured cell volumes were very variable for the diatom Rhizosolenia stolterfothii, indicating that the population included both new and old lines of cells with respect to the formation of sexual auxospores. No 
Table 1b. Volume and carbon data for dominant phytoplankton and protozoan species

\begin{tabular}{|c|c|c|c|c|}
\hline $\begin{array}{c}\text { Taxa } \\
\text { (Station) }\end{array}$ & $\begin{array}{c}\text { Depth range } \\
\text { (m) }\end{array}$ & $\begin{array}{l}\text { Mean volume } \\
\qquad\left(\mu \mathrm{m}^{3}\right)\end{array}$ & $\begin{array}{c}\text { Range in vol. } \\
\qquad\left(\mu \mathrm{m}^{3}\right)\end{array}$ & $\begin{array}{l}\text { Mean carbon } \\
\left(\mathrm{pgC} \text { cell }^{-1}\right)\end{array}$ \\
\hline \multicolumn{5}{|l|}{ Phytoplankton } \\
\hline R. stolterfothii $(\mathrm{M})$ & $2-60$ & 48400 & $11,259-100,800$ & 1616 \\
\hline \multirow[t]{2}{*}{ G. aureolum (F) } & $2-24$ & 3847 & $3201-5121$ & 589 \\
\hline & $24-60$ & 3511 & $2715-6177$ & 540 \\
\hline \multirow[t]{3}{*}{ Flagellates (E5) } & $2-12$ & 44 & $2.4-398$ & 8.8 \\
\hline & $12-24$ & 30 & $2.4-153$ & 6.1 \\
\hline & $24-60$ & 20 & $2.4-102$ & 4.2 \\
\hline \multicolumn{5}{|l|}{ Protozoa } \\
\hline Gyrodinium sp. (F) & $2-24$ & 14900 & $14400-15100$ & 2110 \\
\hline Noctiluca $(\mathrm{F})$ & $2-24$ & $14,100,000$ & - & {$[38500]$} \\
\hline Helicostomella sp. (E5) & $12-24$ & 13900 & $9500-25500$ & 1100 \\
\hline
\end{tabular}

consistent variation in mean cell volume with depth was detected. By contrast, ranges in cell volume for Gyrodinium aureolum and $G$. aff. spirale were small, as expected for naked dinoflagellates undergoing asexual reproduction, although cells of $G$. aureolum below the thermocline were somewhat smaller than those above. The variations in size of the flagellates at E5 were probably related to changes in species composition within the water column. Mean volume appears to have been correlated with abundance so that the largest cells were found in the thermocline and the smallest in the bottom water.

\section{Bacteria (Table 2)}

The numbers of bacteria were highest at the frontal station, ranging from $1.7 \times 10^{6}$ cells $\mathrm{ml}^{-1}$ in the surface samples to $4.0-4.4 \times 10^{5}$ cells $\mathrm{ml}^{-1}$ at depths greater than $36 \mathrm{~m}$ where chlorophyll levels and phytoplankton densities were also low (Fig. 6, Table 1a). A similar distribution in relation to chlorophyll was observed at the stratified station where a maximum of $3.9 \times 10^{5}$ cells $\mathrm{ml}^{-1}$ was found in the thermocline. In the mixed waters bacterial numbers showed no obvious relationship with depth, varying from 5.5 to $6.8 \times 10^{5}$ cells $\mathrm{ml}^{-1}$. The mean densities in the upper $60 \mathrm{~m}$ of the water column in general reflect differences in the phytoplankton standing stock at the 3 stations and ranged from $8.5 \times 10^{5}$ cells $\mathrm{ml}^{-1}$ at the frontal station $(\mathrm{F})$, to $6.2 \times 10^{5}$ cells $\mathrm{ml}^{-1}$ at the mixed water station (M) and $3.0 \times 10^{5}$ cells $\mathrm{ml}^{-1}$ at the stratified station (E5).

The relative proportions of rods and cocci also differed with depth, rods predominating especially in the surface waters of the frontal station. These rods attained their largest size of 0.22 to $0.28 \mu \mathrm{m}^{3}$ at the depth where bacteria were most numerous, perhaps reflecting the availability of nutrients in the water
Table 2. Numbers, proportion and cell volumes of bacterial rods " and cocci, as a function of depth (m)

\begin{tabular}{|c|c|c|c|}
\hline \multirow[t]{2}{*}{ Depth (m) } & \multirow[b]{2}{*}{$\begin{array}{l}\text { Bacteria ml-1 } \\
\left(\times 10^{5}\right) \text { Relative } \\
\text { proportion of } \\
\text { rods },(\%) \text { in } \\
\text { brackets }\end{array}$} & \multicolumn{2}{|c|}{ Mean Volume } \\
\hline & & $\begin{array}{l}\text { Rods : } \\
\left(\mu \mathrm{m}^{3}\right)\end{array}$ & $\begin{array}{l}\text { Cocci } \\
\left(\mu \mathrm{m}^{3}\right)\end{array}$ \\
\hline \multicolumn{4}{|c|}{ Station F } \\
\hline $2-12$ & $16.5(65)$ & 0.219 & 0.110 \\
\hline $12-24$ & 11.5 (69) & 0.130 & 0.050 \\
\hline $24-36$ & $6.5(44)$ & 0.107 & 0.046 \\
\hline $36-48$ & $4.0(64)$ & 0.105 & 0.041 \\
\hline $48-60$ & $4.4(44)$ & 0.101 & 0.038 \\
\hline \multicolumn{4}{|c|}{ Station M } \\
\hline $2-12$ & $6.5(62)$ & 0.183 & 0.052 \\
\hline $12-24$ & $5.9 \quad(56)$ & 0.134 & 0.046 \\
\hline $24-36$ & $6.5 \quad(57)$ & 0.131 & 0.057 \\
\hline $36-48$ & $6.8(58)$ & 0.221 & 0.045 \\
\hline $48-60$ & $5.5(57)$ & 0.091 & 0.045 \\
\hline \multicolumn{4}{|c|}{ Station E5 } \\
\hline $2-12$ & $2.8(60)$ & 0.173 & 0.051 \\
\hline $12-24$ & $3.9(58)$ & 0.275 & 0.054 \\
\hline $24-36$ & $2.9(61)$ & 0.152 & 0.045 \\
\hline $36-48$ & $3.0 \quad(56)$ & 0.160 & 0.048 \\
\hline $48-60$ & $2.4(47)$ & 0.140 & 0.049 \\
\hline Rods includ & occo-bacilli & & \\
\hline
\end{tabular}

column. Ferguson and Rublee (1976) have suggested that cocci are generally characteristic of low nutrient waters, and may represent dormant or 'starved' bacteria (also see Stevenson, 1978; Fuhrman et al,, 1980).

\section{Zooplankton (Table 3)}

Highest densities of microzooplankton at the stratified and frontal stations occurred in the upper $12 \mathrm{~m}$, with copepod eggs and nauplii dominant at E5. 
Table 3a. Vertical distribution of major microzooplankton groups (no $\mathrm{m}^{-3}$ )

\begin{tabular}{|llrrrrrr|}
\hline \multirow{2}{*}{ Taxa } & Station & \multicolumn{5}{c|}{ Depth (m) } \\
& & $2-12$ & $12-24$ & $24-36$ & $36-48$ & $48-60$ \\
\hline Invertebrate & E5 & 403 & 56 & - & - & 56 \\
larvae & $\mathrm{F}$ & 1756 & 3342 & 1284 & 491 & 328 \\
& $\mathrm{M}$ & 672 & 1884 & 3766 & 2087 & 3206 \\
Calanoid & E5 & 7395 & 1009 & 56 & - & 112 \\
copepods & $\mathrm{F}$ & - & 48 & 109 & - & 109 \\
& $\mathrm{M}$ & 1526 & 1578 & 814 & 611 & 612 \\
Cyclopoid & E5 & 3495 & 4314 & 1457 & 224 & 280 \\
copepods & $\mathrm{F}$ & 3787 & 5901 & 1940 & 711 & 765 \\
& $\mathrm{M}$ & 489 & 1120 & 509 & 407 & 102 \\
Copepod eggs & $\mathrm{E} 5$ & 39 & 25 & 6 & 2 & 3 \\
and nauplii & $\mathrm{F}$ & 9 & 11 & 4 & 2 & 2 \\
(x 10-3) & $\mathrm{M}$ & 7 & 6 & 4 & 4 & 4 \\
\hline
\end{tabular}

At the mixed water station the vertical distribution of total microzooplankton was relatively uniform, although particular groups did show consistent trends with depth; copepod eggs and nauplii were dominant at densities similar to those observed at the frontal station.

The most significant feature of the vertical distributions of the major groups of mesozooplankton $(>200 \mu \mathrm{m})$ (Table $3 \mathrm{~b})$ was the influence of thermal stratification. At E5 the copepods were the most abundant group and showed maximum densities in the region of the thermocline (12 to $24 \mathrm{~m}$ ) even in the daytime profiles, whereas invertebrate larvae, pteropods and euphausiids were all aggregated in the

Table 3b. Vertical distribution of major mesozooplankton groups (no $\mathrm{m}^{-3}$ )

\begin{tabular}{|llrrrrr|}
\hline \multirow{2}{*}{ Taxa } & Station & \multicolumn{5}{c|}{ Depth (m) } \\
& & $2-12$ & $12-24$ & $24-36$ & $36-48$ & $48-60$ \\
\hline Copepoda & E5 & 49 & 92 & 41 & 6 & 5 \\
(x 10-2) & F & 1 & 14 & 8 & 6 & 6 \\
& M & 48 & 33 & 31 & 36 & 33 \\
Amphipoda & E5 & - & - & - & 3 & 1 \\
& F & 22 & 126 & 107 & 59 & 49 \\
& M & 12 & - & 20 & 20 & 61 \\
Euphausiacea & E5 & 108 & 67 & 56 & 4 & 3 \\
& F & 7 & 111 & 84 & 24 & 15 \\
& $\mathrm{M}$ & - & - & - & - & - \\
Pteropoda & E5 & 2366 & 134 & 22 & 11 & 311 \\
& $\mathrm{~F}$ & 487 & 580 & 302 & 120 & 142 \\
& $\mathrm{M}$ & 37 & 20 & 31 & 10 & 71 \\
Chaetognatha & E5 & 54 & 44 & 66 & 18 & 35 \\
& $\mathrm{~F}$ & 48 & 32 & 36 & 66 & 57 \\
& $\mathrm{M}$ & 48 & 40 & 10 & 30 & 20 \\
& & & & & & \\
\hline
\end{tabular}

surface $12 \mathrm{~m}$. In the frontal region numbers of copepods were relatively low throughout the water column, but amphipods were a more important component than at the other 2 stations. In the mixed water copepods dominated, with the highest densities in the surface layer and a relatively uniform distribution below $12 \mathrm{~m}$. Also invertebrate larvae (predominantly gastropods, bivalves and echinoderms) were more numerous than in either the frontal or stratified waters.

Data on the distributions of copepods (Table $3 \mathrm{c}$ ) show that Calanus helgolandicus occurred at all 3 stations, but in low densities compared with the smaller calanoids Paracalanus parvus and Pseudocalanus elongatus. The first of these 2 species was concentrated in the region of the thermocline at E5 but was relatively evenly distributed with depth at the other 2 stations. Pseudocalanus similarly exhibited aggregations in the region of the thermocline in the well

Table 3c. Vertical distribution of dominant copepods (no $\mathrm{m}^{-3}$ )

\begin{tabular}{|c|c|c|c|c|c|c|}
\hline \multirow[t]{2}{*}{ Taxa } & \multirow[t]{2}{*}{ Station } & \multicolumn{5}{|c|}{ Depth (m) } \\
\hline & & $2-12$ & $12-24$ & $24-36$ & $36-48$ & $48-60$ \\
\hline Calanus & E5 & 134 & 12 & 90 & 99 & 99 \\
\hline \multirow[t]{2}{*}{ helgolandicus } & $\mathrm{F}$ & 83 & 154 & 70 & 31 & 20 \\
\hline & M & - & 51 & 61 & 41 & 61 \\
\hline Paracalanus & E5 & 549 & 1533 & - & 12 & 13 \\
\hline \multirow[t]{2}{*}{ parvus } & $\mathrm{F}$ & 70 & 312 & 158 & 145 & 154 \\
\hline & M & 598 & 591 & 672 & 293 & 310 \\
\hline \multirow{3}{*}{$\begin{array}{l}\text { Pseudocalanus } \\
\text { elongatus }\end{array}$} & E5 & 3109 & 6131 & 2387 & 226 & 190 \\
\hline & $F$ & 8 & - & 193 & 218 & 287 \\
\hline & $M$ & - & 253 & 550 & 878 & 931 \\
\hline \multirow{3}{*}{$\begin{array}{l}\text { Temora } \\
\text { longicomis }\end{array}$} & E5 & - & - & - & - & - \\
\hline & $\mathrm{F}$ & 8 & 110 & 146 & 116 & 109 \\
\hline & $M$ & - & 61 & 81 & 122 & 61 \\
\hline \multirow{3}{*}{$\begin{array}{l}\text { Metridia } \\
\text { lucens }\end{array}$} & E5 & - & 403 & 583 & 109 & 111 \\
\hline & $\mathrm{F}$ & - & - & - & - & - \\
\hline & M & - & - & - & - & - \\
\hline \multirow{3}{*}{$\begin{array}{l}\text { Centropages } \\
\text { spp. }\end{array}$} & E5 & 27 & - & - & 6 & - \\
\hline & $\mathrm{F}$ & 16 & 22 & 6 & 1 & 8 \\
\hline & $M$ & 500 & 305 & 254 & 295 & 214 \\
\hline \multirow[t]{3}{*}{ Acartia spp. } & E5 & + & - & - & - & - \\
\hline & $F$ & 31 & 82 & 23 & 4 & 3 \\
\hline & $\mathrm{M}$ & 3542 & 1730 & 1415 & 1751 & 1588 \\
\hline \multirow[t]{3}{*}{ Oithona spp. } & E5 & 968 & 1098 & 1098 & 160 & 92 \\
\hline & $F$ & 705 & 665 & 122 & 26 & 42 \\
\hline & $M$ & 134 & 265 & 112 & 183 & 92 \\
\hline
\end{tabular}

stratified water but was essentially absent from the surface layers at both Stations F and M. Temora was found in relatively small numbers only below $12 \mathrm{~m}$ at Stations F and M. By contrast, Metridia lucens was restricted to the well stratified waters where the population maximum was within and just below the thermocline. Centropages spp. were most important in the 
mixed water (predominantly $C$. hamatus) with the highest numbers in the surface $12 \mathrm{~m}$. A similar pattern was observed for Acartia. Oithona spp. (predominantly O. plumifera) were most abundant in the surface layers at stations E5 and F, and the only group to show highest densities in the chlorophyll-rich frontal water were the cyclopoids including Corycaeus and Oncaea.

\section{Partitioning of organic carbon}

\section{Evaluation of carbon determinations}

Although the accuracy of direct measurements of carbon (DOC, POC, micro- and mesozooplankton) is difficult to specify in terms of the overall precision of the analytical and sampling methods, the results are internally consistent in terms of independent checks (e.g. POC versus TPV, carbon versus counts for zooplankton) and of trends relative to physical mixing processes (e.g. uniformity in tidally mixed water at Station $M$ and below the thermocline at Stations $F$ and E5) and to expected associations between parameters (e.g. POC and chlorophyll). For the surface (2 to $12 \mathrm{~m}$ ) layers there is some uncertainty about the relatively high POC values at E5 and $\mathrm{M}$ since the corresponding increases in TPV were not proportional (other profiles also showed this feature at these 2 stations), and also about DOC measurements at F due to possible damage to the Gyrodinium aureolum cells during filtration.

Carbon values derived from microscope counts are more difficult to evaluate, but the patterns of vertical distribution are again consistent with other parameters. Good reproducibility of the microscope counts indicates that the main errors are likely to occur in the conversion of cell volume to carbon. However, some assessment of these is only possible for the phytoplankton. For Station F a comparison of the microscope data (Table 1) which yield a mean volume in the upper $24 \mathrm{~m}$ for Gyrodinium aureolum equivalent to $7 \mathrm{ppm}$ and the particle counter results (Fig. 7) indicates that the former underestimate the cell volume of $G$. aureolum (this could occur as a result of cell shrinkage during preservation). On the other hand, the relationship between cell number and POC (Fig. 8) gives a carbon value of $345 \mathrm{pg} \mathrm{cell}^{-1}$ compared to $589 \mathrm{pg} \mathrm{cell}^{-1}$ (Table 1b) estimated from the microscope measurements. Although any correlation between POC and cell counts will underestimate cell carbon due to bias introduced by increasing properties of non-phytoplankton carbon at lower cell densities, these conclusions do appear contradictory. The diatom population at Station M gave good agreement between the particle size spectrum and the measured values of cell volume but, in this instance, phytoplankton carbon

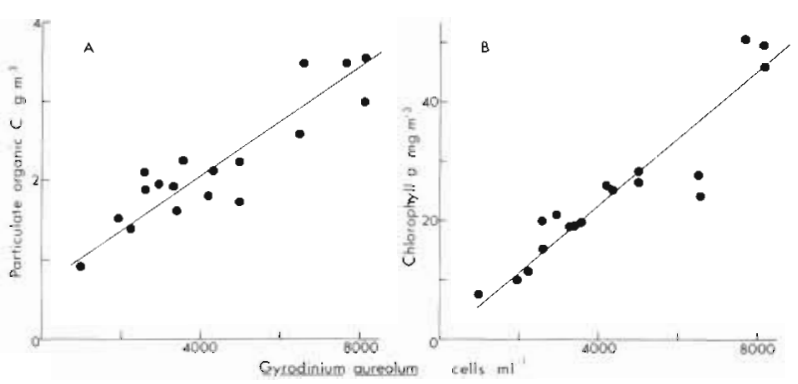

Fig. 8. Comparison of Gyrodinium aureolum cell counts with estimates of particulate organic C (A) and chlorophyll a (B) at Station $\mathrm{F}$. Corresponding regression equations are $\mathrm{C}(\mathrm{mg}$ $\left.\mathrm{m}^{-3}\right)=0.345$ cells $\left(\mathrm{ml}^{-1}\right)+682(\mathrm{r}=0.90, \mathrm{~N}=18)$; and chl.a $\left(\mathrm{mg} \mathrm{m}^{-3}\right)=0.00573$ cells $\left(\mathrm{ml}^{-1}\right)-0.243(\mathrm{r}=0.93, \mathrm{~N}=18)$

cannot be compared directly with POC due to higher proportions of non-phytoplankton carbon.

Another type of variation to emerge from the analyses of particulate material was apparent diel changes in POC to chlorophyll ratios at the mixed and frontal stations (Fig. 9). Although the curves are based on

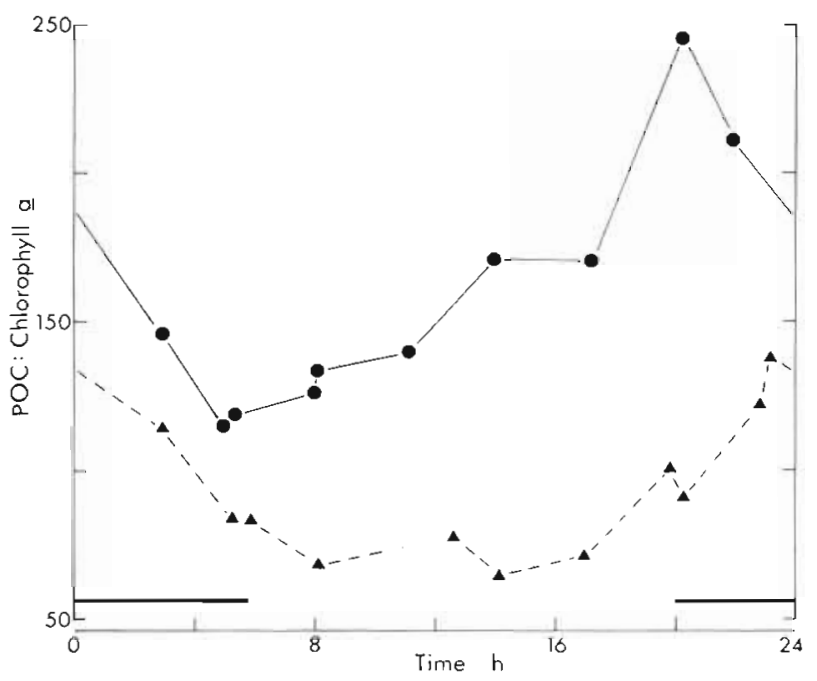

Fig. 9. Diel changes in particulate organic carbon to chlorophyll a ratios at Station F, 2 to $12 \mathrm{~m}$ (solid line) and Station M, 2 to $20 \mathrm{~m}$ (dashed line). Bars: dark period between sunset and sunrise

relatively few data points, the increase in the carbon to chlorophyll ratio during the daylight period when there is net photosynthetic production suggests that they are real. However, precise interpretation is difficult without information on changes in either POC or chlorophyll alone, especially for Station $M$ where more than half the POC appears to be in the form of detritus (Table 4) and there is no correlation between POC and chlorophyll (Fig. 2). In the dinoflagellate bloom the good correlations between POC or chlorophyll a and cell counts (Fig. 8B) suggest that variations in the ratio 
of the 2 parameters were due to diel changes in the composition of the dinoflagellate cells.

These difficulties in estimating the carbon content of planktonic organisms $<200 \mu m$ in diameter mean that the determination of detrital carbon by difference is subject to several sources of considerable potential error. Also, due to various statistical problems in comparing individual carbon (or chlorophyll) values (Banse, 1977), the differences in ratios of carbon in the various compartments can probably be considered significant only if they vary by an order of magnitude or more, or if they change consistently with the known distributions of organisms and hydrographic properties.

\section{Comparison between stations (Table 4)}

In the well stratified water at E5 chlorophyll concentrations exceeded $0.5 \mathrm{mg} \mathrm{m}^{-3}$ only within the thermocline at a depth of 19 to $25 \mathrm{~m}$ (Fig. 2). This layer was sampled mainly in the 12 to $24 \mathrm{~m}$ fraction and, in addition to the peak in phytoplankton carbon, gave maxima for bacteria and protozooplankton carbon as well as dissolved organic carbon (DOC). The microand mesozooplankton, on the other hand, were abundant throughout the upper $24 \mathrm{~m}$. Notable features of the surface water were the high values for particulate organic carbon (POC) and total particle volume (TPV), apparently due to the presence of a large amount of

Table 4. Vertical distribution of organic carbon $\left(\mathrm{mg} \mathrm{m}^{-3}\right)$, total particle volume (ppm) and chlorophyll $\left(\mathrm{mg} \mathrm{m}^{-3}\right)$ at E5, F and $\mathrm{M}$

\begin{tabular}{|c|c|c|c|c|c|}
\hline Profile & $2-12$ & $12-24$ & $\begin{array}{l}\text { Depth }(\mathrm{m}) \\
24-36\end{array}$ & $36-48$ & $48-60$ \\
\hline \multicolumn{6}{|l|}{ E5 (Profile 30, $0900 \mathrm{~h}$ ) } \\
\hline Dissolved organic carbon (DOC) & 1367 & 1520 & 1117 & 1270 & 1280 \\
\hline Particulate organic carbon (POC) & 404 & 209 & 190 & 143 & 228 \\
\hline Phytoplankton & 17.7 & 17.2 & 4.2 & 4.0 & 4.2 \\
\hline Bacteria & 3.8 & 7.9 & 3.5 & 3.6 & 2.5 \\
\hline Protozoa & 1.8 & 8.0 & 0.9 & 0.5 & 0.9 \\
\hline Microzooplankton & 13.7 & 10.1 & 2.1 & 0.2 & 3.9 \\
\hline Mesozooplankton & 29.0 & 27.9 & 20.2 & 14.0 & 11.2 \\
\hline 'Detritus' & 369 & 166 & 179 & 134 & 216 \\
\hline Chlorophyll a & 0.17 & 0.39 & 0.16 & 0.14 & 0.12 \\
\hline Phaeopigment & 0.05 & 0.11 & 0.04 & 0.07 & 0.06 \\
\hline Total particle volume (TPV) & 1.44 & 1.25 & 0.92 & 0.59 & 0.61 \\
\hline \multicolumn{6}{|l|}{ F (Profile 47, $1530 \mathrm{~h}$ ) } \\
\hline Dissolved organic carbon & 1703 & 1340 & 1250 & 1090 & 1133 \\
\hline Particulate organic carbon (POC) & 2096 & 834 & 223 & 206 & 220 \\
\hline Phytoplankton & 1604 & 604 & 79 & 40 & 42 \\
\hline Bacteria & 35.2 & 13.4 & 5.4 & 3.7 & 3.2 \\
\hline Protozoa & 57.9 & 25.0 & 3.4 & 4.1 & 3.0 \\
\hline Microzooplankton & 5.5 & 9.9 & 5.0 & 3.3 & 3.8 \\
\hline Mesozooplankton & 5.8 & 15.9 & 8.5 & 8.1 & 8.8 \\
\hline 'Detritus'" & 394 & 182 & 130 & 155 & 168 \\
\hline Chlorophyll a & 19.94 & 7.62 & 1.23 & 0.64 & 0.58 \\
\hline Phaeopigment & 0.34 & 1.80 & 0.08 & 0.20 & 0.29 \\
\hline Total particle volume (TPV) & 25.56 & 11.41 & 1.37 & 1.50 & 1.33 \\
\hline \multicolumn{6}{|l|}{$\mathrm{M}$ (Profile 13, $1230 \mathrm{~h}$ ) } \\
\hline Dissolved organic carbon (DOC) & 1630 & 1570 & 1960 & 1410 & 1870 \\
\hline Particulate organic carbon (POC) & 350 & 269 & 245 & 216 & 263 \\
\hline Phytoplankton. & 76 & 85 & 95 & 92 & 102 \\
\hline Bacteria & 10.3 & 7.1 & 7.2 & 10.9 & 4.6 \\
\hline Protozoa & 5.5 & 6.7 & 7.4 & 7.6 & 4.9 \\
\hline Microzooplankton & 4.0 & 3.9 & 3.2 & 3.2 & 3.9 \\
\hline Mesozooplankton & 16.3 & 15.5 & 13.0 & 13.9 & 14.9 \\
\hline 'Detritus' & 255 & 166 & 132 & 102 & 148 \\
\hline Chlorophyll a & 1.42 & 1.52 & 1.68 & 1.62 & 1.52 \\
\hline Phaeopigment & 0.43 & 0.36 & 0.45 & 0.45 & 0.45 \\
\hline Total particle volume (TPV) & 3.76 & 3.29 & 3.25 & 3.07 & 3.37 \\
\hline \multicolumn{6}{|c|}{ - Estimated by subtracting the $<200 \mu \mathrm{m}$ plankton fractions from POC } \\
\hline \multicolumn{6}{|c|}{$\begin{array}{l}\text { Coccoid cyanobacteria, } 0.8 \text { to } 1.2 \mu \mathrm{m} \text { in diameter, were present in all samples but are not included in biomass estimates } \\
\text { Densities were generally }<10^{3} \text { cells } \mathrm{ml}^{-1} \text { except in the surface water at } \mathrm{F} \text { which gave } 2.7 \times 10^{4} \mathrm{cells} \mathrm{ml}^{-1}\end{array}$} \\
\hline
\end{tabular}


detrital material. Below the thermocline, levels of POC and plankton carbon were generally low, and consistent with there being little or no growth of the autotrophs in the bottom water.

At Station $F$, the surface dinoflagellate bloom gave POC and TPV values in excess of $2 \mathrm{~g} \mathrm{~m}^{-3}$ and $25 \mathrm{ppm}$ respectively in the 2 to $12 \mathrm{~m}$ fraction. DOC, bacteria and protozooplankton also showed pronounced maxima in this layer. By contrast, the zooplankton were relatively uniformly distributed with highest carbon values for 12 to $24 \mathrm{~m}$, just below the main Gyrodinium population and associated with a peak in phaeopigment levels. Higher TPV values for the bottom water than at E5 seem to have been due to the phytoplankton (mainly $G$. aureolum) forming a greater proportion of the POC rather than to the sinking of detrital material from the bloom

Both dissolved and particulate organic carbon were evenly distributed throughout the water column at Station $M$ although some anomalies were apparent. For example, the lowest levels of phytoplankton carbon and chlorophyll were observed at 2 to $12 \mathrm{~m}$, whereas both POC and TPV showed maximum values in this surface layer. Compared with water below the thermocline at Stations E5 and $F$, the mixed water had a similar POC content but gave higher TPV values. This was probably due to the abundance of diatoms which, on account of their vacuoles, have a high volume to carbon ratio. Also the average concentration of DOC at $M$ exceeded that at either of the other 2 stations.
Relations between compartments of organic carbon (Table 5)

Particulate organic carbon, even with the inclusion of the $>200 \mu \mathrm{m}$ mesozooplankton carbon (Table 4), constituted generally $20 \%$ or less of the dissolved organic carbon. The only exception to this was in the Gyrodinium bloom where the highest observed levels of POC, corresponding to chlorophyll a concentrations of $-50 \mathrm{mg} \mathrm{m}^{-3}$, were about twice those of DOC. Note, however, that disruption of any fragile cells during filtration will have caused a reduction in POC and corresponding increase in DOC. In surface samples, the proportions of POC that could be attributed to the phytoplankton ranged from $<5 \%$ at E5 to $70 \%$ or more within the dinoflagellate bloom.

Phytoplankton carbon to chlorophyll ratios for Stations $F$ and $M$ showed no significant changes with depth. Previous estimates for Gyrodinium aureolum populations based on regression analysis (Pingree et al., 1982) have been somewhat higher $(\sim 100)$ but variations due to sampling at different times of the day (Fig. 9) and different stages of the bloom are expected. By contrast, the ratios for diatom populations at Station $M$ were 3 to 4 times greater than those for spring diatom populations (Fasham et al., 1983) despite the low mean light levels to which they were being exposed. The increase in the phytoplankton carbon to chlorophyll ratio towards the surface at E5 may reflect real differences related to the light environment of the cells, or a greater proportion of heterotrophic flagel-

Table 5. Ratios between components of organic carbon at Stations E5, F and M

\begin{tabular}{|c|c|c|c|c|c|c|}
\hline \multirow{2}{*}{ Component } & \multirow{2}{*}{ Station } & \multicolumn{5}{|c|}{ Depth (m) } \\
\hline & & $2-12$ & $12-24$ & $24-36$ & $36-48$ & $48-60$ \\
\hline \multirow{3}{*}{ POC/DOC } & E5 & 0.29 & 0.14 & 0.17 & 0.11 & 0.18 \\
\hline & $\mathrm{F}$ & 1.25 & 0.63 & 0.18 & 0.19 & 0.19 \\
\hline & M & 0.21 & 0.17 & 0.13 & 0.15 & 0.14 \\
\hline \multirow{3}{*}{ Phytoplankton $\mathrm{C} / \mathrm{POC}$} & E5 & 0.04 & 0.08 & 0.02 & 0.03 & 0.02 \\
\hline & $\mathrm{F}$ & 0.77 & 0.72 & 0.35 & 0.19 & 0.19 \\
\hline & M & 0.22 & 0.32 & 0.39 & 0.43 & 0.39 \\
\hline \multirow{3}{*}{ Phytoplankton C/Chlorophyll a } & E5 & 104 & 44 & 26 & 29 & 35 \\
\hline & $F$ & 80 & 79 & 64 & 63 & 72 \\
\hline & M & 54 & 56 & 57 & 57 & 67 \\
\hline \multirow{3}{*}{ Bacteria C/Heterotroph C } & E5 & 0.09 & 0.15 & 0.13 & 0.20 & 0.14 \\
\hline & $F$ & 0.34 & 0.21 & 0.25 & 0.19 & 0.17 \\
\hline & M & 0.31 & 0.21 & 0.24 & 0.30 & 0.16 \\
\hline \multirow{3}{*}{ Bacteria C/Phytoplankton C } & E5 & 0.21 & 0.46 & 0.83 & 0.90 & 0.60 \\
\hline & $\mathrm{F}$ & 0.02 & 0.02 & 0.07 & 0.09 & 0.08 \\
\hline & M & 0.14 & 0.08 & 0.08 & 0.12 & 0.05 \\
\hline \multirow{3}{*}{ Mesozooplankton C/Phytoplankton C } & E5 & 1.64 & 1.62 & 4.81 & 3.50 & 2.67 \\
\hline & $\mathrm{F}$ & 0.004 & 0.03 & 0.11 & 0.20 & 0.21 \\
\hline & M & 0.21 & 0.18 & 0.14 & 0.15 & 0.15 \\
\hline
\end{tabular}


lates (which cannot be distinguished from autotrophic forms in the cell counts) above the thermocline.

Bacteria formed a substantial proportion, generally 10 to $30 \%$, of total heterotroph carbon at all depths at each of the 3 stations. Relative to the phytoplankton which probably forms the primary source of organic material for bacterial growth, they were most important in the stratified waters at E5, suggesting that phytoplankton growth rates were high at this station. By contrast, the bacteria to phytoplankton carbon ratio for the dinoflagellate bloom was more than an order of magnitude lower, even though the highest standing crops of bacteria were found in this situation (Table 4).

The ratios of mesozooplankton carbon to phytoplankton carbon in the surface water at Stations $F$ and E5 varied by nearly 3 orders of magnitude. At $F$ the mesozooplankton was scarce in both absolute (Table 4) and relative terms, suggesting that there may have been active avoidance of the dinoflagellates by copepods and other herbivores comparable to that reported by Fiedler (1982) and Huntley (1982) for Gymnodinium blooms off the coast of California. Below the dinoflagellate layer the mesozooplankton increased proportionately by almost two orders of magnitude to reach about $20 \%$ of phytoplankton carbon. The relative abundance of mesozooplankton carbon at E5 also increased with depth, but for the upper $60 \mathrm{~m}$ of the water column exceeded the phytoplankton carbon by a factor of about 2. At night this dominance by the mesozooplankton would have been more marked due to the upward migration of organisms from below $60 \mathrm{~m}$ into the surface layers. In the mixed water at Station $M$ the mesozooplankton carbon formed 15 to $18 \%$ of the phytoplankton carbon at all depths.

\section{CONCLUSIONS}

The distributions of plankton carbon at the 3 stations are summarised in Fig. 10 and Table 6. In each case the proportions of plankton carbon were similar for the 0 to $24 \mathrm{~m}$ and 24 to $60 \mathrm{~m}$ layers, although below the thermocline at E5 and $F$ the mean total concentration was relatively low compared to the surface and included a larger proportion of mesozooplankton. The main differences between the stations were in the vertical distribution, abundance and species composition of the phytoplankton and in the relative importance of the different groups of heterotrophs.

Previous studies of the phytoplankton and zooplankton communities in the western English Channel (Harvey et al., 1935; Digby, 1950; Grall and Jacques, 1964; Grall et al., 1971; Holligan and Harbour, 1977; Maddock et al., 1981) as well as investigations on the distributions of organisms in relation to the Ushant

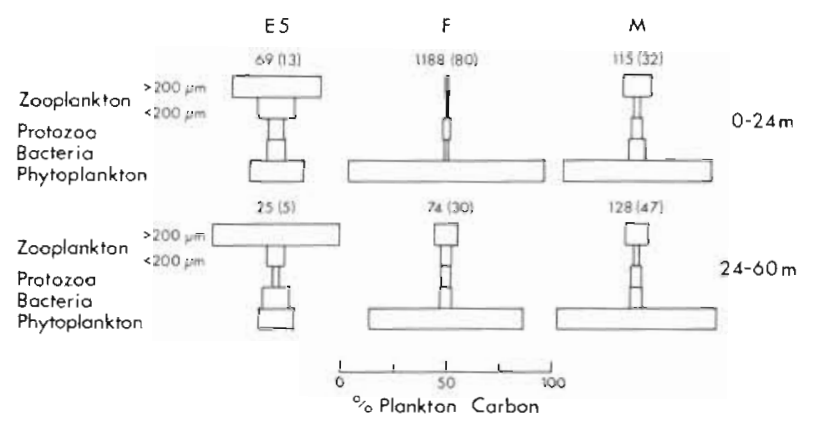

Fig. 10. Relative distributions of organic carbon in zooplankton, protozoans, bacteria and phytoplankton in the 0 to $24 \mathrm{~m}$ and 24 to $60 \mathrm{~m}$ layers on the reference profiles at Stations E5, $F$ and $M$. The values for each histogram give the mean plankton carbon concentration ( $\mathrm{mg} \mathrm{m}^{-3}$ ) and, in parentheses, the proportion of total particulate carbon $(<200 \mu \mathrm{m})$ that can be assigned to the plankton

Table 6. Total standing stocks $\left(\mathrm{g} \mathrm{C} \mathrm{m}^{-2}\right)$ of phytoplankton (autotrophs) and heterotrophs at E5, F and M

\begin{tabular}{|c|c|c|c|}
\hline & E5 & F & M \\
\hline Water depth (m) & 120 & 96 & 76 \\
\hline Phytoplankton ${ }^{1,2}$ & $0.42(0.40)$ & $26.50 \quad(3.5)$ & 7.03 \\
\hline Heterotrophs ${ }^{2}$ & 3.07 & 3.18 & 2.33 \\
\hline \multicolumn{4}{|c|}{$\begin{array}{l}{ }^{1} \text { The } 2 \text { values for Stations E5 and F correspond to surface } \\
\text { t thermocline layers and, in parentheses, bottom layer } \\
{ }^{2} \text { Values for the whole water column were determined by } \\
\text { extrapolation of data for the } 48 \text { to } 60 \text { m layer (Table } 4 \text { ) to } \\
\text { the bottom }\end{array}$} \\
\hline
\end{tabular}

frontal system (Holligan, 1981 and cited references) confirm that the plankton observations at Stations E5, F and $M$ in July 1981 (Tables 1 and 3) are typical of the midsummer period. Thus, in the stratified and frontal waters the dinoflagellates and flagellates had replaced the spring diatoms and the zooplankton included many intermediate or offshore species (Colebrook et al., 1961), whereas in the mixed water at Station $M$ the diatoms had persisted and the zooplankton was neritic in character.

Values for the standing crops of chlorophyll generally fall within the ranges of previous measurements for the summer period (Holligan, 1981; Pingree et al., 1982) although those for the low chlorophyll profiles at E5 were more typical of the area of maximum stratification in the central Celtic Sea (unpubl. own observations). The Gyrodinium aureolum populations have been a characteristic feature of the frontal region since 1975. Comparative data for the standing crop of zooplankton are not available, although Harvey (1950) gives an annual average quantity of $1.5 \mathrm{~g} \mathrm{~m}^{-2}$ dry weight (equivalent to about $0.5 \mathrm{~g} \mathrm{C} \mathrm{m}^{-2}$ ) for the waters off Plymouth, Steele (1956) quates maximum values of $5 \mathrm{~g} \mathrm{C} \mathrm{m}^{-2}$ for the North Sea and English Channel which 
presumably related to the period immediately after the spring diatom outburst, and Adams and Baird (1968) found average summer standing crops of 30 to $56 \mathrm{mg}$ dry weight $\mathrm{m}^{-3}$ for the stratified waters of the northern North Sea. There are no earlier reports of bacterial numbers in the English Channel, but the standing stocks at Stations E5, F and M fall within the ranges previously reported for coastal waters (for a review see van Es and Meyer-Reil, 1982).

We suggest therefore that, despite possible modifications due to the patchiness of organisms, the plankton carbon distributions shown in Fig. 10 represent different types of food web which develop each year in response to different conditions of vertical (tidal) mixing. Their dynamic properties are considered by Holligan et al. (1984) in relation to experimental measurements of photosynthesis and community respiration. Here the ecological implications of widely varying autotroph to heterotroph biomass ratios are briefly discussed.

Variations in the relative proportions of autotrophs and groups of heterotrophs (Table 5, Fig. 10) reflect either imbalances between producers and consumers, as tend to occur at the time of the spring diatom outburst in temperate waters, or different production to biomass (P/B) ratios for the dominant species (Dickie, 1972; Banse and Mosher, 1980). For the phytoplankton populations, in particular, $\mathrm{P} / \mathrm{B}$ ratios are likely to be variable due to the effects of light and nutrient availability on net carbon assimilation.

The dinoflagellate bloom at Station F appears to represent a special case of imbalance, in which the possible suppression of grazing and the capacity of Gyrodinium aureolum to sequester nitrate from below the seasonal thermocline (Holligan et al, 1984) lead to an increasing and persistent dominance of the plant cells in terms of biomass. This situation, however, is probably not stable in a given area for periods $>1 \mathrm{mo}$ (Holligan et al., 1983) due to a combination of light and nutrient limitation of the plant growth rate and physical dispersion of the cells by water movement, but no studies have yet been made of the fate of the phytoplankton carbon when such blooms collapse.

Analysis of the photosynthesis and respiration data for Station $M$ in relation to the vertical distribution of chlorophyll (Holligan et al., 1984) indicates that net production was restricted by the low photosynthesis to respiration ratio for the production as a whole, and was probably positive only on sunny days. In this situation the diatoms appear to survive through re-suspension by bottom tidal mixing, and fluctuations in production are likely to occur over time scales comparable to those in surface irradiance (i. e. sunny versus cloudy weather patterns). The large size of the plant cells will favour direct consumption by herbivorous mesozooplankton although, even if the latter show high $\mathrm{P} / \mathrm{B}$ ratios, a relatively large standing crop of slow growing autotrophs will always be required to support grazing activity.

In the stratified water at E5, which is representative of summer hydrographic conditions for the greater part of the shelf area around the British Isles (Pingree et al,, 1978), the seasonal thermocline creates a more favourable light environment for the phytoplankton so that positive net primary production is maintained even on low-light days. However, the factors that allow relatively high biomass of heterotrophs to persist for several months are not precisely understood, and numerical modelling (Vinogradov and Menshutkin, 1977) of this type of ecosystem is now required to show how the observed pattern of carbon distribution is likely to be maintained on the basis of present knowledge of growth efficiencies for the main groups of organisms. Although marine planktonic food webs are often assumed to be pyramidal with a given biomass of autotrophs supporting successively smaller biomasses of herbivores and carnivores, situations comparable to E5 (Fig. 10) are not uncommon (Raymont, 1980) and indeed may be typical of stratified conditions. For example, Mullin and Brooks (1970) showed that zooplankton to phytoplankton carbon ratios change from 0.3 in April/May to 2.1 in May/June and 1 to 2 during July and August in the coastal waters off California. Dominance by the heterotrophs indicates a more efficient utilisation of the plant carbon in stratified waters, with relatively small losses to the benthic community.

No comparative information on the role of bacteria in re-mineralisation processes and in the transfer of organic matter within the food web (Williams, 1981) under different hydrographic conditions is yet available. At E5, where the biomass of bacteria was comparable to that of phytoplankton (Table 5), consumption of bacteria by flagellates may make a significant contribution to secondary production at higher trophic levels. By contrast, at Stations F and M, the bacteria generally formed less than $10 \%$ of the phytoplankton carbon and are likely to have been relatively more important in terms of nutrient regeneration. The lack of experimental evidence for such suggestions emphasises the need for quantitative observations on the transfer of carbon within the different food chains that develop in the English Channel each year as a result of differences in tidal mixing.

Acknowledgements. We thank the Master, Officers and crew of R. R. S. 'Frederick Russell' for assistance at sea. We are grateful to Dr. Linda Maddock for help with computer analysis of the data; to Dr. P. J. Le B. Williams for valuable discussions, and to Drs. J. Le Fèvre and G.-A. Paffenhöfer, and to 2 referees for many useful comments. We wish to acknowledge receipt of a NERC Postgraduate Fellowship to Ms. E. A. 
S. Linley and funds from a Royal Society Senior Research Fellowship to R. C. Newell. Financial support for this work was received from the Ministry of Agriculture Food and Fisheries (U. K.).

\section{LITERATURE CITED}

Adams, J. A., Baird, I. E. (1968). Chlorophyll a and zooplankton standing stock in the North Sea. Annales Biologiques 25: 93-94

Banse, K. (1977) Determining the carbon-to-chlorophyll ratio of natural phytoplankton. Mar Biol. 41: 199-212

Banse, K., Mosher, S. (1980). Adult body mass and annual production/biomass relationships of field populations. Ecol. Monogr. 50: 355-379

Beers, J. R., Reid, F. M. H., Stewart, G. L. (1975). Microplankton of the North Pacific central gyre. Population structure and abundance, June 1973. Int. Revue ges. Hydrobiol. 60: $607-638$

Beers, J. R., Reid, F. M. H., Stewart, G. L. (1982). Seasonal abundance of the microplankton population in the North Pacific central gyre. Deep Sea Res. 29: 227-245

Colebrook, J. M., Glover, R. S., Robinson, G. A. (1961). Continuous plankton records: contributions towards a plankton atlas of the north-eastern Atlantic and the North Sea. Bull. mar. Ecol. 5; 67-80

Collins, K. J., Williams, P. J. Le B. (1977). An automated photochemical method for the determination of dissolved organic carbon in sea and estuarine waters. Mar. Chem. 5 ; 123-141

Dewey, J. M. (1976). Rates of feeding, respiration and growth of the rotifer Brachionus plicatilis and the dinoflagellate Noctiluca miliaris in the laboratory. Ph. D. thesis, University of Washington

Dickie, L. M. (1972). Food chains and fish production. ICNAF spec. Publ. 6: 381-385

Digby, P. S. B. (1950). The biology of the small planktonic copepods off Plymouth. J. mar. biol. Ass. U. K. 29: 393-438

Doetsch, R. N., Cook, T M. (1973). Introduction to bacteria and their ecobiology. University Park Press, Baltimore

Eppley, R. W., Reid, F. M. H., Strickland, J. D. H. (1970). Estimates of phytoplankton crop size, growth rate and primary production. In: Strickland, J. D. H. (ed.) The ecology of the plankton off La Jolla, California in the period April through September, 1967 Bull. Scripps Inst. Oceanogi $17: 33-42$

Es, F. B. van, Meyer-Reil, L.-A. (1982). Biomass and metabolic activity of heterotrophic marine bacteria. Adv. microb. Ecol. 2: 111-171

Fasham, M. J. R., Holligan, P. M., Pugh, P. R. (1983). The spatial and temporal development of the spring phytoplankton bloom in the Celtic Sea, April 1979. Prog. Oceanogr. 12: 87-145

Ferguson, R. L., Rublee, P. (1976). Contribution of bacteria to standing crop of coastal plankton. Limnol. Oceanogr. 21: $141-145$

Fiedler, P. C. (1982). Zooplankton avoidance and reduced grazing responses to Gymnodinium splendens (Dinophyceae). Limnol. Oceanogr. 27: 961-964

Fraser, J. H. (1965). Zooplankton indicator species in the North Sea. Serial atlas of the marine environment. American Geographical Society, Folio 8

Fuhrman, J A. (1981). Influence of method on the apparent size distribution of bacterioplankton cells: epifluorescence microscopy compared to scanning electron microscopy. Mar. Ecol. Prog. Ser 5: 103-106
Fuhrman, J. A., Ammerman, J. W., Azam. F. (1980). Bacterioplankton in the coastal euphotic zone: distribution, activity and possible relationships with phytoplankton. Mar. Biol. 60: 201-207

Gershey, R. M., Mackinnon, M. D., Moore, R. M., Williams, P. J. LeB. (1979). Comparison of three oxidation methods for the analysis of dissolved organic carbon in seawater. Mar. Chem. 7: 289-306

Grall, J. R., Jacques, G. (1964). Etude dynamique et variations saisonnières du plancton de la région de Roscoff. Cah. Biol. mar. 5: 423-455

Grall, J. R., Le Fèvre-Lehoerff, G., Le Fèvre, J. (1971). Observations sur la distribution du plancton a proximité d'Ouessant en juin 1969 et ses relations avec le milieu physique. Cah. océanogr. 23: 145-169

Grice, G. D., Harris, R. P., Reeve, M. R., Heinbokel, J. F., Davis, C. O. (1980). Large scale enclosed water column ecosystems. J. mar. biol. Ass. U. K. 60: 401-413

Harvey, H. W. (1950). On the production of living matter in the sea off Plymouth. J. mar. biol. Ass. U. K. 29: 97-137

Harvey, H. W., Cooper, L. H. N., Lebour, M. V., Russell, F. S. (1935). Plankton production and its control. J. mar. biol. Ass. U. K. 20: 407-442

Herman, A. W., Mitchell, M. R. (1981). Counting and identifying copepods species with an in situ electronic zooplankton counter. Deep Sea Res. 28: 739-755

Hobbie, J. E., Daley, R. J., Jasper, S. (1977). Use of Nuclepore filters for counting bacteria by fluorescence microscopy. Appl. environ. Microbiol. 35: 1225-1228

Hobbie, J. E., Holm-Hansen, O., Packard, T. T., Pomeroy, L. R., Sheldon, R. W., Thomas, J. P., Wiebe, W. J. (1972). A study of the distribution and activity of microorganisms in ocean water. Limnol. Oceanogr. 17: 544-555

Holligan, P. M. (1981). Biological implications of fronts on the northwest European continental shelf. Phil. Trans. R. Soc. A 302: $547-562$

Holligan, P. M., Harbour, D. S. (1977). The vertical distribution and succession of phytoplankton in the western English Channel in 1975 and 1976. J. mar. biol. Ass. U. K. 57 : $1075-1093$

Holligan, P. M., Viollier, M., Dupouy, C., Aiken, J. (1983). Satellite studies on the distributions of chlorophyll and dinoflagellate blooms in the western English Channel. Cont. Shelf Res., in press.

Holligan, P. M., Williams, P. J. Le B, Purdie, D., Harris, R. P. (1984). The photosynthetic and respiratory activities, and nitrogen supply of summer plankton populations in stratified, frontal and mixed shelf waters. In preparation

Holm-Hansen, O., Lorenzen, C. J., Holmes, R. W., Strickland, J. D. H. (1965). Fluorometric determination of chlorophyll. J. Cons. perm. int. Explor. Mer 30: 3-15

Huntley, M. E. (1982). Yellow water in La Jolla Bay, California, July 1980. II Suppression of zooplankton grazing. J. exp. mar. Biol. Ecol. 63: 81-91

Kovala, P. E., Larrance, J. D. (1966). Computation of phytoplankton cell numbers, cell volume, cell surface and plasma volume per litre, from microscopical counts. University of Washington, Dept. of Oceanography, Spec. Rep. No. 38: 1-21

Krey, J. von (1956). Die Trophie küstennaher Meeresgebiete. Kieler Meeresforsch. 12: 46-64

Lohmann, H. (1908). Untersuchungen zur Feststellung des vollständigen Gehaltes des Meeres an Plankton. Wiss. Meeresunters. N. F. Abt. Kiel 10: 129-370

Lorenzen, C. J. (1966). A method for the continuous measurement of in vivo chlorophyll concentration. Deep Sea Res. 13: $223-227$ 
Lorenzen, C. J. (1967). Determination of chlorophyll and phaeophytin: spectrophotometric equations. Limnol. Oceanogr 12: 343-346

Maddock, L., Boalch, G. T., Harbour, D. S. (1981). Populations of phytoplankton in the western English Channel between 1964 and 1974 . J. mar. biol. Ass. U. K. 61: 565-583

Mullin, M. A., Brooks, E. R. (1970). The ecology of the plankton off La Jolla, California, in the period April through September 1967. Part VII. In: Strickland, J. D. H. (ed.) Production of the planktonic copepod, Calanus helgolandicus. Bull. Scripps Inst. Oceanogr. 17: 80-103

Pingree, R. D., Holligan, P. M., Mardell, G. T. (1978). The effects of vertical stability on phytoplankton distributions in the summer on the northwest European shelf. Deep Sea Res. 25: 1011-1028

Pingree, R. D., Mardell, G. T., Holligan, P. M., Griffiths, D. K., Smithers, J. (1982). Celtic Sea and Armorican current structure and the vertical distributions of temperature and chlorophyll. Cont. Shelf Res. 1: 99-116

Platt, T., Mann, K. H., Ulanowicz, R. E. (ed.) (1981). Mathematical in biological oceanography. Monographs on oceanographic methodology UNESCO Press 7: 1-156

Raymont, J. E. G. (1980). Plankton and productivity in the oceans, Vol. 1, Phytoplankton. Pergamon Press, Oxford

Ricker, W. E. (1973). Linear regressions in fishery research. J. Fish. Res. Bd Can. 30: 409-434

Sheldon, R. W., Prakash, A., Sutcliffe, W. H. Jr. (1972). The size distribution of particles in the ocean. Limnol. Oceanogr. 17: $327-340$
Smetacek, V. (1981). The annual cycle of protozooplankton in the Kiel Bight. Mar Biol. 63: 1-11

Southward, A. J. (1962). The distribution of some plankton animals in the English Channel and approaches. II. Surveys with the Gulf high-speed sampler, 1958-60. J. mar. biol. Ass. U. K. 42: 275-375

Steele, J. H. (1956). Plant production on the Fladen Ground. J. mar biol. Ass. U. K. 35: 1-33

Stevenson, H. L. (1978). A case for bacterial dormancy in aquatic systems. Microb. Ecol. 4: 127-133

Straškrabová, V., Sorokin, Y. I. (1972). Determination of cell size of micro-organisms for the calculation of biomass. In: Sorokin, Y I., Kadota, M. (ed.) I. B. P. Handbook (23). Blackwell, Oxford, p. 48-50

Strickland, J. D. H., Parsons, T. R. (1972). A practical handbook of seawater analysis. Bull. Fish. Res. Bd Can. 167: $1-310$

UNESCO (1968). Zooplankton sampling. Monogr. Oceanogr. Methodology 2: 1-174

UNESCO (1974). A review of methods used for quantitative phytoplankton studies. Unesco Techn. Pap. Mar. Sci. 18: $1-27$

Vinogradov, M. E., Menshutkin, V. V. (1977). The modelling of open-sea ecosystems. In: Goldberg, E. D., McCave, I. N., O'Brien, J. J., Steele, J. H. (ed.) The sea, Vol. 6. Wiley \& Sons, New York, p. 891-921

Williams, P. J. Le B. (1981). Incorporation of microheterotrophic processes into the classical paradigm of the planktonic food web. Kieler Meeresforsch. Sonderheft 5: 1-28

This paper was presented by Dr. A. J. Southward; it was accepted for printing on August 2, 1983 